\title{
Molecular mechanism of gossypol mediating CCL2 and IL-8 attenuation in triple-negative breast cancer cells
}

\author{
SAMIA S. MESSEHA, NAJLA O.ZARMOUH, PATRICIA MENDONCA, \\ CAROLYN COTTON and KARAM F.A. SOLIMAN \\ Division of Pharmaceutical Sciences, College of Pharmacy and Pharmaceutical Sciences, \\ Florida A\&M University, Tallahassee, FL 32307, USA
}

Received October 14, 2019; Accepted April 28, 2020

DOI: $10.3892 / \mathrm{mmr} .2020 .11240$

\begin{abstract}
Chronic inflammation associated with cancer is characterized by the production of different types of chemokines and cytokines. In cancer, numerous signaling pathways upregulate the expression levels of several cytokines and evolve cells to the neoplastic state. Therefore, targeting these signaling pathways through the inhibition of distinctive gene expression is a primary target for cancer therapy. The present study investigated the anticancer effects of the natural polyphenol gossypol (GOSS) in triple-negative breast cancer (TNBC) cells, the most aggressive breast cancer type with poor prognosis. GOSS effects were examined in two TNBC cell lines: MDA-MB-231 (MM-231) and MDA-MB-468 (MM-468), representing Caucasian Americans (CA) and African Americans (AA), respectively. The obtained $\mathrm{IC}_{50} \mathrm{~s}$ revealed no significant difference between the two cell lines' response to the compound. However, the use of microarray assays for cytokine determination indicated the ability of GOSS to attenuate the expression levels of cancer-related cytokines in the two cell lines. Although GOSS did not alter CCL2 expression in MM-468 cells, it was able to cause 30\% inhibition in TNF- $\alpha$-stimulated MM-231 cells. Additionally, IL-8 was not altered by GOSS treatment in MM-231 cells, while its expression was inhibited by $60 \%$ in TNF- $\alpha$-activated MM-468 cells. ELISA assays supported the microarray data and indicated that CCL2 expression was inhibited by $40 \%$ in MM-231 cells, and IL-8 expression was inhibited by $50 \%$ in MM-468 cells. Furthermore, in MM-231 cells, GOSS inhibited CCL2 release via the repression of IKBKE, CCL2 and MAPK1 gene expression. Additionally, in MM-468 cells, the compound downregulated the release of IL-8 through
\end{abstract}

Correspondence to: Dr Karam F.A. Soliman, Division of Pharmaceutical Sciences, College of Pharmacy and Pharmaceutical Sciences, Florida A\&M University, G134 H New Pharmacy Building, 1415 S. Martin Luther King Boulevard, Tallahassee, FL 32307, USA E-mail: karam.soliman@famu.edu

Key words: gossypol, breast cancer, gene expression, CCL2, IL-8, signaling pathways repressing $I L-8, M A P K 1, M A P K 3, C C D C 88 A, S T A T 3$ and $P I K 3 C D$ gene expression. In conclusion, the data obtained in the present study indicate that the polyphenol compound GOSS may provide a valuable tool in TNBC therapy.

\section{Introduction}

Cancer evolves through different abnormal molecular signaling pathways, including chronic inflammation events. Dysregulation of the inflammatory process might lead to chronic inflammation that contributes to many diseases, including cancer, cardiovascular, diabetes, lung diseases, Alzheimer's, and autoimmune diseases $(1,2)$. The relationship between cancer and inflammation is well-established (3). Chronic inflammation is a hallmark of tumorigenesis that significantly mediates various stages in cancer, including cellular changes, initiation, promotion, proliferation, survival, invasion, angiogenesis, and metastasis (1), leading to approximately 15 to $20 \%$ of all cancer-related deaths worldwide (4).

Meanwhile, breast cancer (BC) is a heterogeneous disease (5) that demonstrated its link to inflammation (4). In the United States, $15 \%$ of the diagnosed BC cases are classified as basal-like BC subtype according to the molecular profile $(6,7)$. Triple-negative breast cancer (TNBC) is the most aggressive and metastatic subgroup that comprises up to $75 \%$ of the basal-like $\mathrm{BC}(8,9)$, and it is known to be more profound among African American (AA) patients than Caucasian American (CA) patients (10). In TNBC cells, the absence of three specific receptors: Estrogen (ER), progesterone (PR) and human epidermal growth factor (Her2/neu) is a difficult challenge in treating the disease $(11,12)$. Even though, TNBC has an initial significant response to many chemotherapy agents (13), approximately $30 \%$ of the patients experience poor prognosis and treatment failure after repeated exposure to these agents, leading to a median survival of one year (14).

Chronic inflammation-associated cancer is characterized by the presence of leukocyte infiltration, prominently macrophages that produce chemokines and cytokines (15). These cytokines are the critical mediators of communication between neoplastic cells in the inflammatory tumor microenvironment (16). Particularly in BC, two chemokines, IL-8, and CCL2 regulate tumor angiogenesis $(17,18)$, survival, and metastasis of cancer cells (19). In addition to their chemotactic 
role, these two chemokines enable the recruitment of other cells, including monocytes, neutrophils, $\mathrm{T}$ lymphocytes, and NK cells (20). Under normal conditions, the pro-inflammatory cytokine, tumor necrosis factor- $\alpha$ (TNF- $\alpha$ ), mediates the inflammatory pathway and controls inflamed cells (1). In an aggressive BC environment, TNF- $\alpha$ is excessively produced by the tumor-associated macrophages (TAMs) $(21,22)$ and substantially upregulates many genes involved in cancer cell proliferation, invasion, and metastasis (23).

In normal tissue, homeostasis of cell number and rational cell functions are precisely controlled and maintained through the release of growth-promoting signals. Cell signal dysregulation and cell evolvement to the neoplastic state may impair growth suppressor genes that could lead to prolonging proliferative signaling, cell death resistance, angiogenesis, and even triggering invasion and metastasis (24). In the context of cancer, many signaling pathways, including JAK-STAT, MAPK, PI3K-AKT, NF-қB, Notch, and Wnt, have received substantial attention as targets in cancer therapeutic intervention. The Janus kinase (JAK)-signal transducer and activator of transcription (STAT) pathway is involved in the cellular response to cytokines and play a pivotal role in the growth factor signaling and apoptosis. Impaired JAK-STAT signaling can lead to tumorigenesis, either directly or indirectly (25). The Mitogen-Activated Protein Kinase (MAPK) pathway (also known as ERK pathway) is essential in stimulating survival, proliferation, migration, and cell adhesion through signals transduction from cytokines and growth factors (19). Parallel to the MAPK pathway, the activated phosphoinositide 3-kinase-protein kinase B (PI3K-AKT) pathway mediates cancer cell metabolism and regulates proliferation. Additionally, this pathway activates other signaling pathways, including Wnt and NF-қB (26), which in turn regulates different genes involved in inflammation, cell viability, proliferation, and apoptosis (27) in BC and many others cancer types.

Plant-derived compounds have been thoroughly screened for their potency in preventing and treating cancer (28). Numerous studies have demonstrated the medicinal importance of the polyphenol compound, gossypol (GOSS) (2,20-binaphthalene)-8,80-dicarboxaldehyde, 1,10,6,60,7,70-hexahydroxy-5,50-diisopropyl-3,30-dimethyl, a minor constituent of cotton (Gossypium hirsutum L.) seeds (29-31). GOSS has various biological activities, including antifertility, antiviral, antimicrobial, and antioxidative activity (32). Moreover, the anti-proliferative, anti-metastatic, and apoptotic effects of GOSS have been documentd against several human cancers, including colon, prostate, glioma, adrenal, leukemia (24,33-37), in addition to breast cancer $(28,38-40)$. The drug combination is critical to accomplish a synergistic therapeutic effect (41) and to overcome the resistance mechanisms of many diseases, including cancer (42). GOSS has been found to induce apoptosis in various types of human cancer cells in combination with low doses of dexamethasone (43), doxorubicin (44), taxanes (45), and valproic acid (46).

Many studies have demonstrated the anticancer effect of GOSS in BC, including the TNBC subtype, MDA-MB-231 (MM-231) cells. However, studying the racial perspective of the compound effects on MDA-MB-468 (MM-468), and its gene-related mechanism of action in comparison to MM-231 cells has never been addressed. Moreover, the potential effect of GOSS on the proinflammatory cytokines, IL-8 and CCL2 has not been reported prior to this work. Therefore, the current study is designed to compare the anticancer effect of GOSS on two TNF- $\alpha$-stimulated human TNBC cell lines: MM-231 and MM-468, representing Caucasian (CA) and African American (AA) women, respectively (47). We hypothesized that GOSS could modulate the expression of genes involved in many cellular signaling pathways that mediate the regulation of diverse cancer-related cytokines/chemokines.

\section{Materials and methods}

Materials. The compound GOSS (purity $\geq 90 \%$ ) was purchased from Santa Cruz Biotechnology, Inc. Trypsin-EDTA solution $0.25 \%$ and Alamar Blue ${ }^{\circledR}$ (a sterile buffered solution of resazurin fluorescence dye) were purchased from Sigma-Aldrich; Merck KGaA. Dimethyl sulfoxide (DMSO), penicillin/streptomycin, and Dulbecco's Phosphate Buffer Saline (DPBS) were obtained from the American Type Culture Collection. Dulbecco's Modified Eagle Medium (DMEM), heat-inactivated fetal bovine serum (FBS), and cell culture plates were purchased from VWR International (Radnor). TNF- $\alpha$, Human Cytokine Antibody Array kit (cat. no. AAH-CYT-1000), Human ELISA kits for C-C Motif Ligand 2 [CCL2, also known as monocyte chemoattractant protein-1 (MCP-1), cat. no. ELH-MCP1] and Interleukin-8 (IL-8, also known as CXCL-8, cat. no. ELH-IL-8) were purchased from RayBiotech. TURBO DNA-free ${ }^{\mathrm{TM}}$ kit (cat. no. AM1907) was purchased from Life Technologies, Inc. TRIzol ${ }^{\circledR}$ reagent was purchased from Invitrogen; Thermo Fisher Scientific. An iScript ${ }^{\mathrm{TM}}$ cDNA Synthesis kit (cat. no. 170-8891), SsoAdvanced ${ }^{\mathrm{TM}}$ Universal SYBR ${ }^{\circledR}$ Green Supermix (cat. no. 1725271), Human PCR primers (CCL2, IKBKE, IL-8, STAT3, MAPK1, MAPK3, $C C D C 88 A, P I K 3 C D$, and GAPDH) were purchased from Bio-Rad Laboratories, Inc.

Cell culture. The two immortalized TNBC cell models: MM-231 (https://www.atcc.org/products/all/HTB-26.aspx) and MM-468 (https://www.atcc.org/Products/All/HTB-132. aspx), were purchased from ATCC. Both cell lines were grown in $75-\mathrm{cm}$ TC-flasks at $37^{\circ} \mathrm{C}$ in humidified $5 \% \mathrm{CO}_{2}$ incubator and subculture as required, using trypsin/EDTA $(0.25 \%)$. The routinely used DMEM growth medium contained $4 \mathrm{mM}$ L-glutamine and was supplemented with $10 \%$ FBS (v/v), and $1 \%$ penicillin/streptomycin salt solution $(100 \mathrm{U} / \mathrm{ml}$ and $0.1 \mathrm{mg} / \mathrm{ml}$, respectively). The DMEM experimental medium was the same, except it was phenol-free and was supplemented with $2.5 \%$ FBS as previously reported by others (48).

Cell viability assay. In this experiment, cells were incubated overnight at $37^{\circ} \mathrm{C}$ at a density of $5 \times 10^{4}$ cells/well in 96-well microplates. GOSS powder was reconstituted in DMSO. Both types of cells were treated for $24 \mathrm{~h}$ with $50 \mathrm{ng} / \mathrm{ml}$ of TNF- $\alpha$, in addition to the compound (concentration ranges of 0-100 $\mu \mathrm{M}$ in MM-231 or 0-50 $\mu \mathrm{M}$ in MM-468 cells). Control wells were treated with DMSO at the highest used concentration $(<0.1 \%)$. Blank wells were treated in the same manner but without cells. Alamar Blue ${ }^{\circledR}$ was used to determine cell viability, as described in our previous study (49). The fluorescent-fuchsia 
dye of the reduced resazurin by viable cells was measured at an excitation/emission of 530/590 nm using a Synergy HTX Multi-Reader (BioTek).

Human cytokine/chemokine protein microarray. Cytokine expression microarray analysis was designed based on the data of the cytotoxicity assay. Four flasks for each cell line were incubated overnight with a density of $10 \times 10^{6}$ cells $/ 75-\mathrm{cm}^{2}$ TC flask using the experimental media with $2.5 \%$ FBS. Four flasks for each cell line were incubated overnight with a density of $10 \times 10^{6}$ cells $/ 75-\mathrm{cm}^{2}$ TC flask using the experimental media with $2.5 \%$ FBS. On the next day, the media were discarded, and the cells were treated with $50 \mathrm{ng} / \mathrm{ml} \mathrm{TNF-} \alpha$ and low concentrations of GOSS that slightly impacted the cell viability. MM-231 cells were treated as follows: TNF- $\alpha$ (50 ng/ml), GOSS $(6.25 \mu \mathrm{M})$, and TNF- $\alpha+$ GOSS (50 ng/ml $+6.25 \mu \mathrm{M}$, respectively). Similarly, MM-468 cells were treated with TNF- $\alpha(50 \mathrm{ng} / \mathrm{ml})$, GOSS $(5 \mu \mathrm{M})$, and TNF- $\alpha+$ GOSS $(50 \mathrm{ng} / \mathrm{ml}+5 \mu \mathrm{M}$, respectively). In both experimental sets, control samples were exposed to only the solvent DMSO at a concentration of $<0.1 \%$. After a $24 \mathrm{~h}$ exposure period, the cell-free supernatant of each sample was collected, aliquoted, and stored at $-80^{\circ} \mathrm{C}$ for later use. At the same time, the cells from each flask were pelleted and similarly stored at $-80^{\circ} \mathrm{C}$ for RT-qPCR study. For each cell line, a semi-quantitative method using antibody-coated array membranes was established to measure chemokine/cytokine expression in the cell-free supernatants. The assay was established following the manufacturer protocols. Briefly, four membranes were carefully placed in four chamber-incubation trays and blocked with the provided buffer on a shaker for 30 min at RT. After that, the blocking buffer was decanted, and replaced with $1 \mathrm{ml}$ cell-free supernatant from resting, GOSS-treated, TNF- $\alpha$-stimulated or cotreated cells, and the four membranes were then kept overnight on a low-speed shaker at $4^{\circ} \mathrm{C}$. On the following day, the supernatants were removed from each chamber, and the membranes were washed with the kit washing buffers. Next, $1 \mathrm{ml}$ of freshly constituted biotinylated antibody cocktail was pipetted to each membrane and incubated at RT for $2 \mathrm{~h}$, followed by washing with the same wash buffers. The membranes were incubated again for another $2 \mathrm{~h}$ with $2 \mathrm{ml}$ of diluted horseradish peroxidase-conjugated streptavidin (HRP-Streptavidin) followed by the final washes. Cytokines intensities on the blots were detected as spots using a chemiluminescence cocktail. The blot images were captured using a Flour-S Max Multiimager (Bio-Rad Laboratories, Inc.), and the spot intensities were measured with the Quantity-One Software (Bio-Rad Laboratories, Inc.). The Excel-based data analysis was established, using the Human Cytokine Array software C1000 (CODE: S02-AAH-CYT-1000) from RayBiotech.

Human CCL2 and IL-8 chemokines ELISA study. Enzyme-Linked Immunosorbent Assay (ELISA) kits were used to measure the protein levels $(\mathrm{pg} / \mathrm{ml})$ for both CCL2 and IL- 8 chemokines. Briefly, the standard curves, samples, and reagents were prepared at RT for both chemokines. Standards and samples of $100 \mu 1$ each were incubated with the antibody pre-coated 96-well ELISA microplates for $2.5 \mathrm{~h}$. The supernatant was replaced by $100 \mu \mathrm{l}$ of the freshly constituted biotinylated antibody for another hour, then removed. Streptavidin solution $(100 \mu \mathrm{l})$ was added for $45 \mathrm{~min}$, followed by the addition of $100 \mu \mathrm{l}$ of the substrate reagent for 30-min incubation. Washes were always performed after each step according to the manufacturer's protocol. The reaction was terminated by the addition of $50 \mu \mathrm{l}$ of a stop-solution, and the intensity for the chemokines and the standard were measured at $450 \mathrm{~nm}$ using a Synergy HTX Multi-Reader (BioTek).

RNA isolation and $c D N A$ synthesis. In this assay, the previously- $80^{\circ} \mathrm{C}$-frozen cell pellets were used, as mentioned above in the Human cytokine/chemokine protein microarray study. The total RNA was extracted from each sample using $1 \mathrm{ml}$ of Trizol ${ }^{\circledR}$ reagent and sonicated for $30 \mathrm{sec}$ at RT using VirTishear mechanical homogenizer (LabWrench). Subsequently, $200 \mu \mathrm{l}$ of chloroform was added to each sample, vortexed, incubated at RT for 2-3 min and centrifuged for $15 \mathrm{~min}$ at $10,000 \mathrm{xg}$ and $2-8^{\circ} \mathrm{C}$. The aqueous phase was separated and mixed with $500 \mu \mathrm{l}$ of isopropyl alcohol to precipitate the RNA for different samples. The RNA pellets were then reconstituted in approximately 30-50 $\mu \mathrm{l}$ of nuclease-free water to measure the RNA concentration and purity in each sample using a Nanodrop spectrophotometer (Thermo Fisher Scientific, Inc.). Thereafter, the purified RNA was reverse transcribed into cDNA using an iScript ${ }^{\mathrm{TM}}$ cDNA Synthesis Kit and PCR run as follows: $46^{\circ} \mathrm{C}$ for $20 \mathrm{~min}$ and $95^{\circ} \mathrm{C}$ for $1 \mathrm{~min}$.

Reverse transcription-quantitative PCR (RT-qPCR). In this study, we measured the expression of various genes involved in CCL2 and IL-8 regulation, using qPCR of the Bio-Rad CFX96 Real-Time System (Bio-Rad Laboratories, Inc.) (50). Briefly, the freshly synthesized cDNA $(1 \mu \mathrm{l} ; 200 \mathrm{ng})$ was used for each sample in a final volume of $20 \mu \mathrm{l}(10 \mu \mathrm{l}$ of the $2 \mathrm{x}$ real-time Master Mix, $8 \mu 1$ nuclease-free water, and $1 \mu$ l of primer mix). According to the manufacturer's protocol, the PCR run was performed as follows: Reactants were first incubated at $95^{\circ} \mathrm{C}$ for $2 \mathrm{~min}$, and then 39 cycles of amplification (51) were carried out with each cycle consisting of denaturing at $95^{\circ} \mathrm{C}$ for $10 \mathrm{sec}$, annealing at $60^{\circ} \mathrm{C}$ for $30 \mathrm{sec}$, and melting curve at $65-95^{\circ} \mathrm{C}$ for 5 sec. All qPCR reactions were performed in triplicates for each primer. In this experiment, the used PCR primers were compatible with the different genes under investigation and are summarized in Table I. GAPDH was applied as a reference gene to normalize the mRNA levels for genes of interest.

Statistical analysis. The quantitative data for this study were analyzed using GraphPad Prism 6.2 software. All data points were obtained from the average of at least two independent studies and are expressed as the mean \pm SEM. For the viability assay, $\mathrm{IC}_{50} \mathrm{~s}$ values were determined by nonlinear regression model of $\log$ (inhibitor) vs. normalized response-variable slope on the software with the R2 best fit and the lowest $95 \%$ confidence interval. The significance of the difference between each control and its related treatment groups was determined using one-way ANOVA, followed by Bonferroni's multiple comparison tests. A statistical difference was considered significant at $\mathrm{P}<0.05$ and less. For array blots and ELISA studies, independent (unpaired) Student's t-test was used to verify the significance of the difference between TNF- $\alpha$ vs. control groups, or between TNF- $\alpha$ vs. TNF- $\alpha+$ GOSS groups. 
Table I. List of primers used in reverse transcription-quantitative PCR experiments.

GenBank

Name accession no.
Amplicon context sequence

\begin{tabular}{|c|c|c|}
\hline$M C P 1 / C C L 2$ & NM_002982.4 & $\begin{array}{l}\text { ACTGAAGCTCGCACTCTCGCCTCCAGCATGAAAGTCTCTGCCGCCCTTCTGT } \\
\text { GCCTGCTGCTCATAGCAGCCACCTTCATTCCCCAAGGGCTCGCTCAGCCAGA } \\
\text { TGCAATCAATGCCCCAGTCACCTGCTGTTATAACTTCACCAATAGGAAGATCT } \\
\text { CAGTGCAGAGGCTCGCGAGCTAT }\end{array}$ \\
\hline$I L-8$ & NM_000584.4 & $\begin{array}{l}\text { GAGCACTCCATAAGGCACAAACTTTCAGAGACAGCAGAGCACACAAGCTTC } \\
\text { TAGGACAAGAGCCAGGAAGAAACCACCGGAAGGAACCATCTCACTGTGTG }\end{array}$ \\
\hline$I K B K E$ & NM_014002.4 & $\begin{array}{l}\text { GGCTTGGCTACAACGAGGAGCAGATTCACAAGCTGGATAAGGTGAATTTCAG } \\
\text { TCATTTAGCCAAAAGACTCCTGCAGGTGTTCCAGGAGGAGTGCGTGCAGAA } \\
\text { GTATCAAGCGTCCTTAGTCACACACGGCAAGAGGATGAGGGTGGTGCACGAG }\end{array}$ \\
\hline MAPK1 & NM_002745.4 & $\begin{array}{l}\text { TTCAGCTGGTCAAGATAATGCTTCCCTGGAAAGATGGGCCTGTTAGAAAGCAT } \\
\text { TTCTGCCAGAATGCAGCCTACAGACCAAATATCAATGGACTTGGTGTAGCCCT } \\
\text { TGGAATTCAACATAATTTCTGGAGC }\end{array}$ \\
\hline$M A P K 3$ & NM_002746.3 & $\begin{array}{l}\text { TCTCCATCAGGTCCTGCACAATGTAGACATCTCTCATGGCTTCCAGGGTGGAC } \\
\text { GCCCGCAGAATGTCTCGGATGCCGATGACATTCTCATGGCGGAAGCGCAGCA } \\
\text { GGATCTGGATCTCCCGGAGCGTGCGCTGGCAGTAGGTCTGATGTTCGAAGGG } \\
\text { GCTGATCTTCTTGATGGCCACGC }\end{array}$ \\
\hline CCDC $88 A$ & NM_001365480.1 & $\begin{array}{l}\text { GGAGTTGGGCATTCTGGTTCATGAGTGAGGTACTTTGGGAATTAAGGGTGGA } \\
\text { ATTTTCAACCTGAAGCTTGGCATTCTGTGTTTGAAGAGTGGTATTCTGTTCTTG } \\
\text { TAATGACACTGTCTGCCTCTGAAGTGCAAGAATCTGAGCCTGCAAATTATTGT } \\
\text { TCTGTGTCT }\end{array}$ \\
\hline STAT3 & NM_139276.2 & $\begin{array}{l}\text { GGTGTCACACAGATAAACTTGGTCTTCAGGTATGGGGCAGCGCTACCTGGGT } \\
\text { CAGCTTCAGGATGCTCCTGGCTCTCTGGCCGACAATACTTTCCGAATGCCTCCT } \\
\text { CCTTGGGAATGTCAGGATAGAGATAGACCAGTGGAGACACCAGGATATTGGT }\end{array}$ \\
\hline PIK3CD & NM_005026.4 & $\begin{array}{l}\text { GCGGCTGGAGTTCGACATCAACATCTGCGACCTGCCCCGCATGGCCCGTCTCT } \\
\text { GCTTTGCGCTGTACGCCGTGATCGAGAAAGCCAAGAAGGCTCGCTCCACCAA } \\
\text { GAAGAAGTCCAAGAAGGCGGACTGCCCCATTGCCTGGG }\end{array}$ \\
\hline GAPDH & NM_002046.7 & $\begin{array}{l}\text { GTATGACAACGAATTTGGCTACAGCAACAGGGTGGTGGACCTCATGGCCCAC } \\
\text { ATGGCCTCCAAGGAGTAAGACCCCTGGACCACCAGCCCCAGCAAGAGCACA } \\
\text { AGAGGAAGAGAGAGACCCTCACTGCTGGGGAGTCCCTGCCACAC }\end{array}$ \\
\hline
\end{tabular}

Quantitative mRNA expression was analyzed using CFX 3.1 Manager software for Bio-Rad Laboratories, Inc. All genes were normalized against the expression of the housekeeping gene glyceraldehyde 3-phosphate dehydrogenase (GAPDH) and verified with unpaired Student's t-test.

\section{Results}

GOSS decreases cell viability in MM-231 and MM-468 TNBC cells. The anticancer effects of GOSS were examined in the presence of $50 \mathrm{ng} / \mathrm{ml}$ of TNF- $\alpha$ in both MM-231 and MM-468 cell lines. As indicated in Fig. 1A and B, a highly significant cytotoxic effect $(\mathrm{P}<0.0001)$ was detected at all the tested concentrations ranges $12.5-100 \mu \mathrm{M}$ in $\mathrm{MM}-231$ cells and $1-50 \mu \mathrm{M}$ in MM-468 cells. The obtained $\mathrm{IC}_{50} \mathrm{~s}(19.13 \pm 0.32 \mu \mathrm{M}$ for MM-231 and 23.46 $\pm 0.43 \mu \mathrm{M}$ for MM-468) showed a slightly higher response to the compound in MM-231 cells. Based on the viability studies data, optimum doses of GOSS that causes less than $20 \%$ cell death and $50 \mathrm{ng} / \mathrm{ml}$ of TNF- $\alpha$ were determined for cytokine/chemokine expression study.

GOSS inhibits the release of CCL2 in MM-231 cells and $I L-8$ in MM-468 cells. To understand the mechanism of the antitumor effects of GOSS on TNF- $\alpha$-stimulated MM-231 and MM-468 TNBC cells, we measured the expression of different cytokines/chemokines released in the cell-free supernatants in the presence and the absence of GOSS and $50 \mathrm{ng} / \mathrm{ml}$ of TNF- $\alpha$ (52). Low concentrations of GOSS that slightly impacted the cell viability were used $(6.25 \mu \mathrm{M}$ in MM-231 cells and $5 \mu \mathrm{M}$ in MM-468 cells).

The obtained results show that GOSS repressed the expression of two critical chemokines, CCL2 in MM-231 cells and IL- 8 in MM-468 cells, as indicated by the red frames on both the maps and the blot arrays. In the cytokine blots, AAH-CYT-6, the expression of the cytokine was scarcely noticeable on most of blots presenting the supernatants of both control and GOSS-treated cells (Fig. 2A and B). High expression of CCL2 was observed in both TNF- $\alpha$-treated cell lines (Fig. 2C1 and $\mathrm{C} 2$ ). The intensity of the spot was attenuated in MM-231 cells by the effect of $6.25 \mu \mathrm{M}$ GOSS (Fig. 2D1), the observation that was not showed in MM-468 cells (Fig. 2D2).

Meanwhile, the intensity of IL- 8 was low on the blots presenting the supernatants of both control and GOSS-treated cells (Fig. 3A and B). Indeed, TNF- $\alpha$ has increased IL-8 expression in both cell lines, as indicated on the AAH-CYT-7 
A

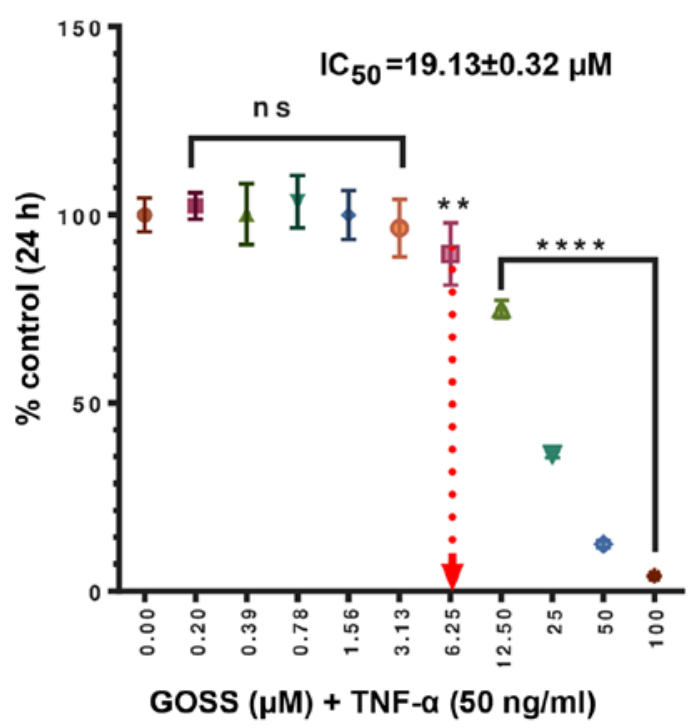

B MM-468 cells

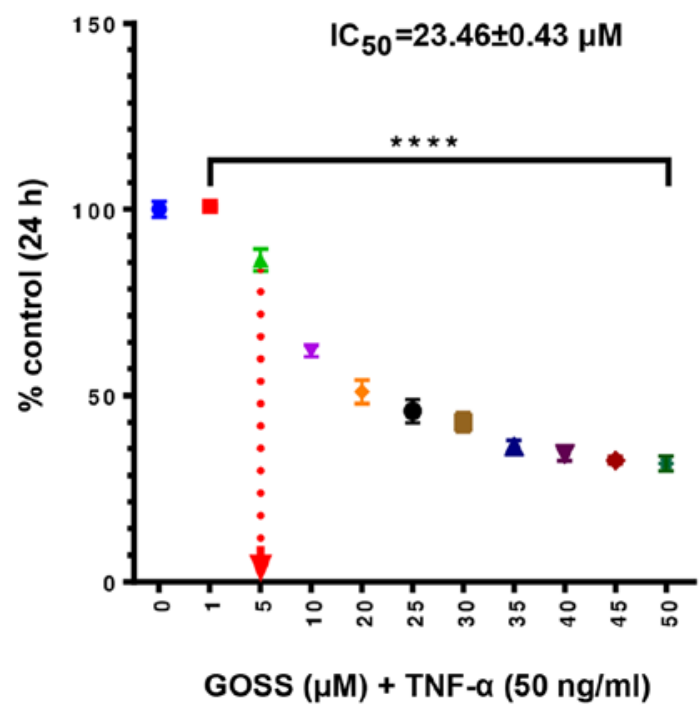

Figure 1. Effect of GOSS and TNF- $\alpha$ on the viability of TNF- $\alpha$-stimulated MM-231 and MM-468 cells. In combination with 50 ng/ml TNF- $\alpha$, cells were treated for $24 \mathrm{~h}$ with GOSS at concentration ranges of (A) 0-100 $\mu \mathrm{M}$ in MM-231 and (B) $0-50 \mu \mathrm{M}$ in MM-468 cells. On the $\mathrm{x}-\mathrm{axis}$, the arrows represent the designated concentrations to be used in the following cytokine expression study. The percentages of cell survival compared with the control were calculated. The data points are presented as the mean \pm SEM of three independent studies $\left(\mathrm{n}=6\right.$ each). ${ }^{* *} \mathrm{P}<0.01,{ }^{* * * *} \mathrm{P}<0.0001$. The significance of the difference between the control and treated groups was determined using one-way ANOVA, followed by Bonferroni's multiple comparisons test. P<0.05 was considered to indicate a statistically significant difference. GOSS, gossypol; ns, not significant; TNF- $\alpha$, tumor necrosis factor $\alpha$.

blots (Fig. 3C1 and C2). The compound GOSS did not reduce the cytokine expression in MM-231 cells (Fig. 3D1). However, an observed decrease was detected in MM-468 cells in the presence of $5 \mu \mathrm{M}$ GOSS (Fig. 3D2).

Both chemokines, CCL2 and IL-8, were quantified as a percentage relative to their control. TNF- $\alpha$ has induced an 8-fold increase in CCL2 expression in MM-231 cells $(\mathrm{P}<0.001)$ (Fig. 4A). The data indicated that the presence of both GOSS and TNF- $\alpha$ significantly attenuated CCL 2 by $30 \%(\mathrm{P}<0.01)$. Similarly, in MM-468 cells (Fig. 4B), a more than 8 -fold increase in the expression of IL-8 $(\mathrm{P}<0.01)$ was quantified in TNF- $\alpha$-stimulated cells and then inhibited by $60 \%$ in the presence of GOSS $(\mathrm{P}<0.05)$. The results show that the GOSS compound did not attenuate IL-8 expression in MM-231 cells (Fig. 4C), nor CCL2 in MM-468 (Fig. 4D). Also, no changes were detected when we compare the control to the GOSS-treated cells in both chemokines of interest.

We further validated the microarray data for only the significantly attenuated chemokines. Protein expression quantification for CCL2 ( $\mathrm{pg} / \mathrm{ml})$ and IL-8 ( $\mathrm{ng} / \mathrm{ml})$ was measured using two independent ELISA assays. Overall, the data for cytokine arrays and ELISA were consistent in both cell lines. The assay indicated a significant increase in CCL2 $(\mathrm{P}<0.001)$ and $\mathrm{IL}-8(\mathrm{P}<0.01)$ in $\mathrm{TNF}-\alpha$-treated vs. resting cells (Fig. 4E and F). The simultaneous presence of GOSS and TNF- $\alpha$ attenuated the expression of CCL2 by $~ 40 \%$ in MM-231 cells $(\mathrm{P}<0.001)$, and IL-8 expression was also reduced by $50 \%$ in $\mathrm{MM}-468$ cells $(\mathrm{P}<0.05)$.

GOSS alters the expression of genes regulating the release of CCL2 in MM-231 cells and IL-8 in MM-468 cells. RT-qPCR was performed to determine the relevance of our data and to elucidate the mechanism by which GOSS impact CCL2 and
IL-8 regulation in MM-231 and MM-468 cells, respectively (Figs. 5 and 6). Profiling the normalized expression of mRNAs in both cell lines provides precise insights into the influence of the compound on signaling pathways-related genes.

The RT-qPCR data presented in Figs. 5A and 6A indicated that mRNAs expressions of $C C L 2$ and $I L-8$ were consistent with those of cytokine microarray and ELISA protein studies in both MM-231 and MM-468 cell lines, respectively. The mRNA's data showed that both cell lines responded to TNF- $\alpha$ and TNF- $\alpha+$ GOSS. In TNF- $\alpha$-stimulated MM-231 cells, CCL2 mRNA expression exhibited a highly significant 32-fold up-regulation $(\mathrm{P}<0.0001)$ (Fig. 5A and Table II). This gene was dramatically repressed by $80 \%$ in the presence of $6.25 \mu \mathrm{M}$ GOSS $(\mathrm{P}<0.0001)$. Furthermore, GOSS repressed two more genes, $I K B K E$ and $M A P K 1$, which are involved in the signaling pathways of TNF- $\alpha$-induced CCL2 release. IKBKE showed a significant increase in expression of $\sim 11$-fold by TNF- $\alpha$ that was repressed to $\sim 53 \%$ by GOSS (Fig. 5B and Table II). The detected up-regulation in MAPKl was non-significant in the TNF- $\alpha$-stimulated cells. However, GOSS was able to suppress significantly $(\mathrm{P}<0.0001)$ its expression by $\sim 39 \%$ (Fig. 5C and Table II).

Similarly, in TNF- $\alpha$-stimulated MM-468 cells, IL-8 mRNA was upregulated by $\sim 65$-fold $(\mathrm{P}<0.0001)$ followed by $60 \%$ downregulation $(\mathrm{P}<0.001)$ when combined with 5.0 $\mu \mathrm{M}$ GOSS (Fig. 6A and Table III). Moreover, a significant fold-increase $(\mathrm{P}<0.01-\mathrm{P}<0.0001)$ was also found in five more genes (Fig. 6B-F and Table III), including $M A P K 1, M A P K 3$, $C C D C 88 A$, STAT3, and PIK3CD that showed the highest increase (3-fold). GOSS repressed the expression of these five genes by almost 40-50\%, as shown in Fig. 6B-F and Table III.

Indeed, the obtained data in this study, including those of the cytokine microarray blots, ELISA, and PCR evaluation, 
Human cytokine antibody array AAH-CYT-6

\begin{tabular}{|c|c|c|c|c|c|c|c|c|c|c|c|c|c|c|c|}
\hline & & A & B & c & D & E & $\mathbf{F}$ & 0 & H & $\mathbf{I}$ & J & $\kappa$ & L & M & N \\
\hline 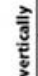 & \begin{tabular}{|l|}
1 \\
2
\end{tabular} & Pos & Pos & NEG & NEG & BLANK & Angiogenin & BONF & $\begin{array}{c}B L C \\
\text { (Cxa.13) }\end{array}$ & BMP-4 & BMP.6 & $\begin{array}{l}\text { Ck beta 8-1 } \\
\text { (Ca23) }\end{array}$ & CNTF & EGF & $\begin{array}{l}\text { Eotaxin-1 } \\
\text { (CQ11) }\end{array}$ \\
\hline 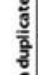 & \begin{tabular}{|l|}
3 \\
4
\end{tabular} & $\begin{array}{l}\text { Eotaxin-2 } \\
\text { (CCL24) }\end{array}$ & $\begin{array}{l}\text { Eotxin-2 } \\
\text { (CCL26) }\end{array}$ & FGF-6 & $\begin{array}{l}\text { FGF.7 } \\
\text { (KGF) }\end{array}$ & Fit-3 Ligand & $\begin{array}{c}\text { Fractalkine } \\
\text { (CX3CL.1) }\end{array}$ & $\begin{array}{r}\text { GCP.2 } \\
\text { (CXCl6) }\end{array}$ & GDNF & GM.CSF & $\begin{array}{l}1.309 \\
\text { (CCL1) }\end{array}$ & IFN-gamma & IGFBP-1 & IGFBP-2 & IGFBP-4 \\
\hline 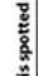 & \begin{tabular}{|l|}
5 \\
6 \\
\end{tabular} & IGF-1 & IL-10 & |L-13 & IL-15 & IL-16 & $\begin{array}{l}\text { IL-1 alpho } \\
\text { (IL-1 FI) }\end{array}$ & $\begin{array}{l}\text { IL-1 beta } \\
\text { (IL-1 F 2) }\end{array}$ & $\begin{array}{l}\text { IL-1 ra } \\
\text { (IL-1F3) }\end{array}$ & $1 \mathrm{~L}-2$ & IL-3 & IL-4 & IL-5 & IL-6 & IL-7 \\
\hline $\begin{array}{l}\text { ते } \\
\text { d. } \\
\text { है } \\
\text { है }\end{array}$ & \begin{tabular}{|l|}
7 \\
8 \\
\end{tabular} & Leptin & $\begin{array}{c}\text { UGHT } \\
\text { (TNFSF 14) }\end{array}$ & $\begin{array}{l}\text { MCP.1 } \\
\text { (CCL2) }\end{array}$ & $\begin{array}{l}\text { MCP.2 } \\
\text { (CCL8) }\end{array}$ & $\begin{array}{c}\text { MCP.3 } \\
\text { (MARC/CCL7) }\end{array}$ & $\begin{array}{l}\text { MCP-4 } \\
\text { (CCL13) }\end{array}$ & M-CSF & $\begin{array}{c}\text { MDC } \\
\text { (CCL22) }\end{array}$ & $\begin{array}{c}\text { MIG } \\
\text { (CXCL9) }\end{array}$ & $\begin{array}{l}\text { MiP.1 delta } \\
\text { (CC.15) }\end{array}$ & $\begin{array}{l}\text { MIP.3 } \\
\text { alpha } \\
\text { (CCL20) }\end{array}$ & $\begin{array}{l}\text { NAP.2 } \\
\text { (CXCL7) }\end{array}$ & $\mathrm{NT}-3$ & $\begin{array}{l}\text { PARC } \\
\text { (CCL18) }\end{array}$ \\
\hline$\approx$ & \begin{tabular}{|l|}
9 \\
10
\end{tabular} & PDGF-B8 & $\begin{array}{l}\text { RANTES } \\
\text { (CCLS) }\end{array}$ & SCF & SDF- 1 alpha & $\begin{array}{l}\text { TARC } \\
\text { (CCL17) }\end{array}$ & TGF beta 1 & TGF beta 3 & TNF alpha & TNF beta & BLANK & BLANK & BLANK & BLANK & pos \\
\hline
\end{tabular}

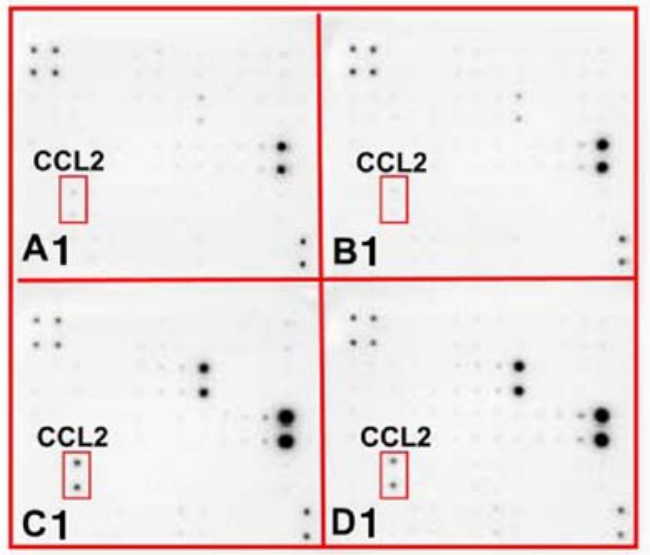

MM-231 cells

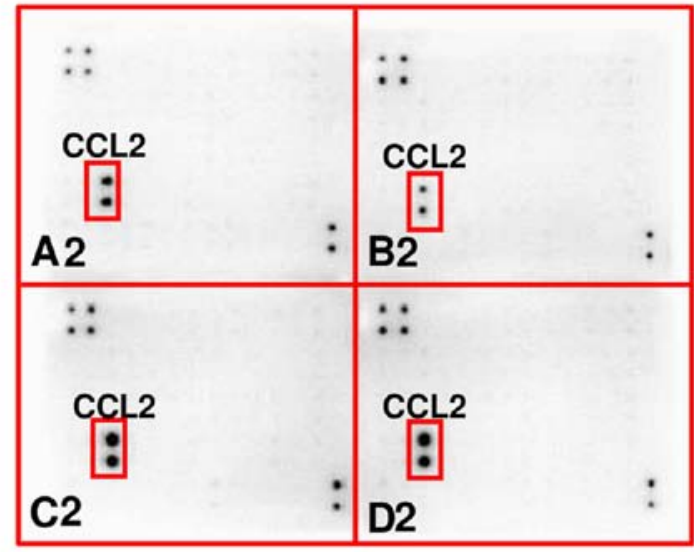

MM-468 cells

Figure 2. Effect of GOSS on cytokine expression in TNF- $\alpha$-stimulated triple-negative breast cancer cells. The human protein microarray AAH-CYT-6 was used to measure chemokine/cytokine expression in the cell-free supernatant. (A1-D1) The four blots represent the supernatants of the following MM-231 cell treatments: (A1) Control, (B1) $6.25 \mu \mathrm{M}$ GOSS, (C1) $50 \mathrm{ng} / \mathrm{ml} \mathrm{TNF-} \alpha$ and (D1) GOSS + TNF- $\alpha$-treated. (A2-D2) The four blots represent the supernatants of the following MM-468 cell treatments: (A2) Control, (B2) $5 \mu$ M GOSS, (C2) $50 \mathrm{ng} / \mathrm{ml} \mathrm{TNF-} \alpha$ and (D2) GOSS + TNF- $\alpha$-treated. Microarray chemiluminescence spotted the changes in only CCL2 cytokine expression that was red-framed on the AAH-CYT-6 array map as well as on all blots. GOSS, gossypol; TNF- $\alpha$, tumor necrosis factor $\alpha$.

\section{Human cytokine antibody array AAH-CYT-7}

\begin{tabular}{|c|c|c|c|c|c|c|c|c|c|c|c|c|c|c|c|}
\hline \multirow{6}{*}{ 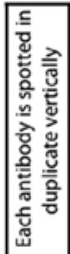 } & & $\mathrm{A}$ & $B$ & c & $D$ & $E$ & $F$ & $G$ & $\mathrm{H}$ & 1 & $J$ & $K$ & $\mathrm{~L}$ & $M$ & $\mathrm{~N}$ \\
\hline & 2 & POS & POS & NEG & NEG & BLANK & $\begin{array}{c}\begin{array}{c}\text { Adiponectin } \\
\text { (ACRP30) }\end{array} \\
\end{array}$ & $A_{g} P_{P}$ & ANGPT2 & $A R$ & Axd & bFGF & beta-NGF & BTC & CC.28 (MEO) \\
\hline & 4 & $\begin{array}{l}\mathrm{CTACK} \\
(\mathrm{CCCL27}) \\
\end{array}$ & Dak & EGFR & $\begin{array}{l}\text { ENA.78 } \\
\text { (CXC.5) } \\
\end{array}$ & $\begin{array}{l}\text { Fas } \\
\text { (Apo-1) }\end{array}$ & FGF-4 & FGF-9 & GCSF & $\begin{array}{c}\text { GIIR Ligand } \\
\text { (TNFSF18) } \\
\end{array}$ & $\begin{array}{c}\text { GITR } \\
\text { (TNFRSF18) } \\
\end{array}$ & GRO $\mathrm{a} / \mathrm{b} / \mathrm{g}$ & $\begin{array}{c}\text { GRO alpha } \\
\text { (CXC1) } \\
\end{array}$ & $\mid \mathrm{HCC}-4$ (CCL16) & HGF \\
\hline & 6 & ICAM-1 (CDS4) & ICAM-3 (CDSO) & 1GFBP.3 & IGFBP-6 & IGF-1R & $\begin{array}{r}14-1 \text { R4 } \\
\text { (ST2) }\end{array}$ & IL-1 RI & $11-11$ & $11-12 p 40$ & $1 L-12$ p 70 & II-17A & IL-2R alpha & $11-6 R$ & $\begin{array}{l}\text { TL-8 } \\
\text { (COCL8) }\end{array}$ \\
\hline & 8 & $\begin{array}{c}\begin{array}{c}\text { FTAC } \\
\text { (CXCL11) }\end{array} \\
\end{array}$ & Lympho-tactin & MiF & $\begin{array}{l}\text { Mip-1 alpha } \\
\text { (CCI3) }\end{array}$ & \begin{tabular}{|c|}
$\begin{array}{c}\text { Mip-1 beta } \\
\text { (CCl4) }\end{array}$ \\
\end{tabular} & \begin{tabular}{|c|}
$\begin{array}{c}\text { Mip. } 3 \text { beta } \\
\text { (CC.19) }\end{array}$ \\
\end{tabular} & $\begin{array}{c}\text { MSP } \\
\text { alpha/beta } \\
\end{array}$ & NT-4 & $\begin{array}{c}\text { OPG } \\
\text { (TNFRSF118) } \\
\end{array}$ & OSM & PLGF & gp 130 & $\begin{array}{c}\begin{array}{c}\text { TNF RIII } \\
\text { (TNFRSF1B) }\end{array} \\
\end{array}$ & $\begin{array}{c}\text { TNF RI } \\
\text { (TNFRSF1A) } \\
\end{array}$ \\
\hline & 10 & TECK (CCL2S) & nIMP.1 & пімР-2 & TPO & \begin{tabular}{|c} 
TRALR3 \\
(TNFASF10C) \\
\end{tabular} & \begin{tabular}{|c|} 
TRALRA \\
(TNFRSF100) \\
\end{tabular} & UPAR & VEGF-A & VEGF-D & BLANK & BLANK & BLANK & BLANK & POS \\
\hline
\end{tabular}

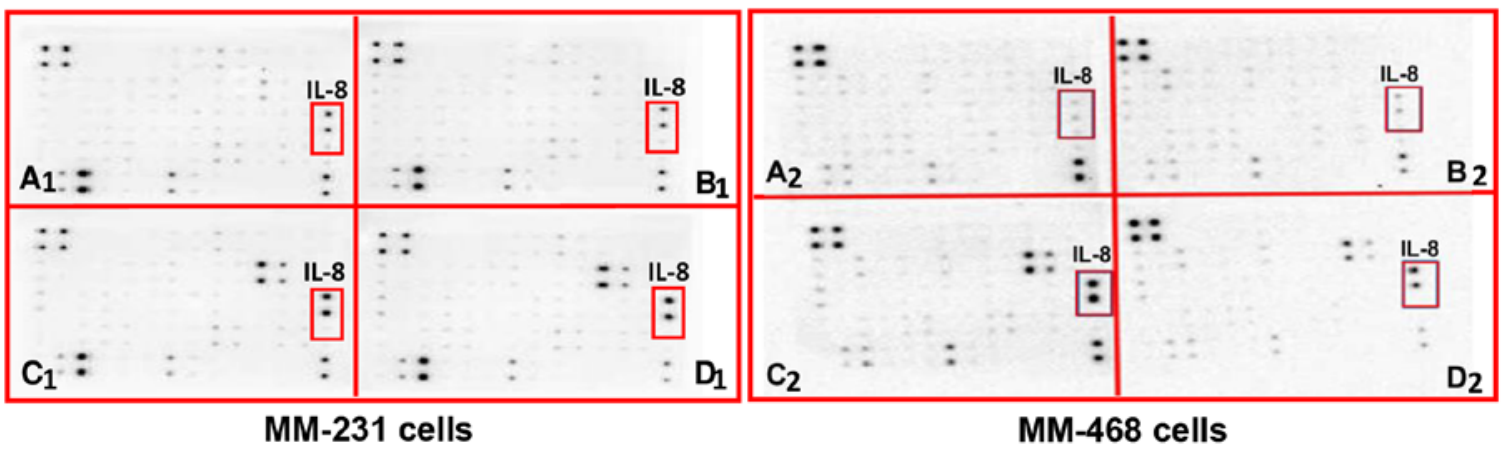

Figure 3. Effect of GOSS on cytokine expression in TNF- $\alpha$-stimulated triple-negative breast cancer cells. The human protein microarray AAH-CYT-7 was established to measure chemokine/cytokine expression in the cell-free supernatant. (A1-D1) The four blots represent the supernatants of the following MM-231 cell treatments: (A1) Control, (B1) $6.25 \mu \mathrm{M}$ GOSS, (C1) $50 \mathrm{ng} / \mathrm{ml}$ TNF- $\alpha$ and (D1) GOSS + TNF- $\alpha$-treated. (A2-D2) The four blots represent the supernatants of the following cell treatments: (A2) Control, (B2) $5 \mu \mathrm{M}$ GOSS, (C2) $50 \mathrm{ng} / \mathrm{ml}$ TNF- $\alpha$, and (D2) GOSS + TNF- $\alpha$-treated. Microarray chemiluminescence determined the changes in only IL- 8 chemokine expression that was red-framed on the AAH-CYT-7 array map as well as on all blots. GOSS, gossypol; TNF- $\alpha$, tumor necrosis factor $\alpha$. 
A

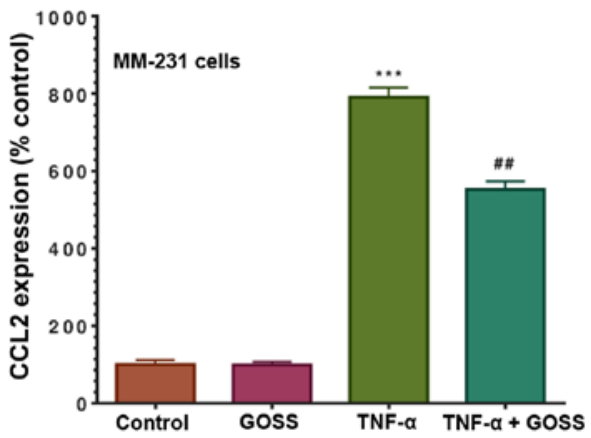

C

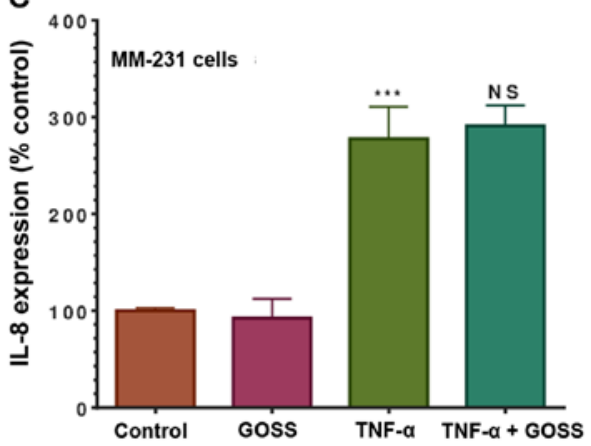

E

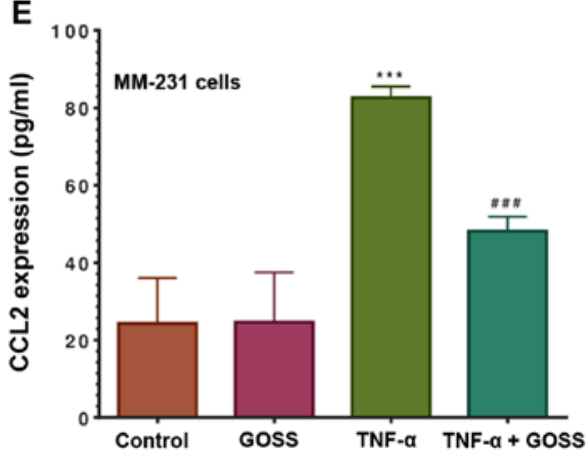

B

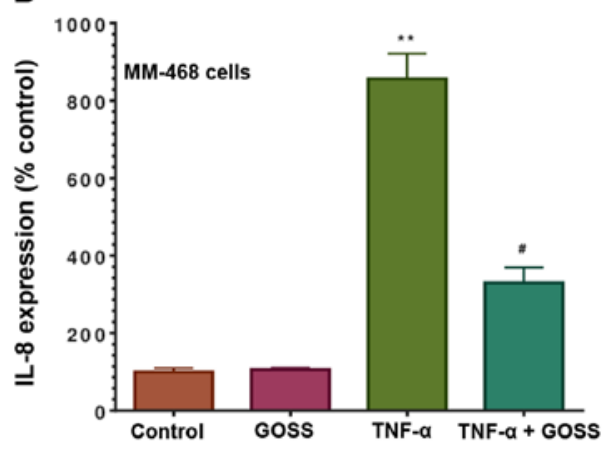

D

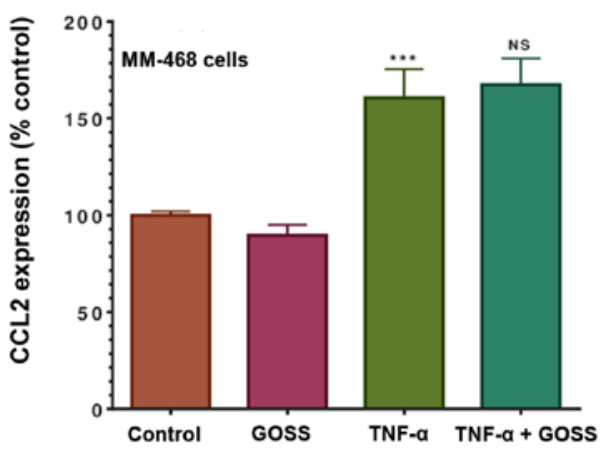

F

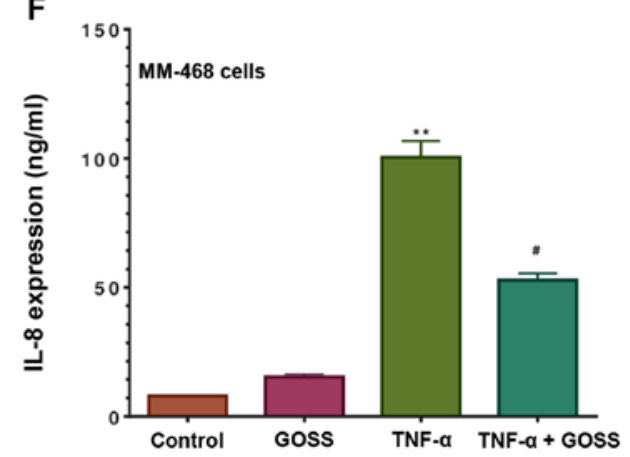

Figure 4. Cytokine array quantification of chemokines inhibited by GOSS in TNF- $\alpha$-stimulated triple-negative breast cancer cell lines. The effect of GOSS on the extracellular cytokine expression was assessed as follows: CCL2 release from (A) MM-231 cells and (D) MM-468 cells, IL-8 release from (B) MM-468 and (C) MM-231 cells. ELISA quantifications (E) for CCL2 released from MM-231 cells and (F) for IL-8 released from MM-468 cells. The normalized data show the cytokine expression in four sets of experimental cell supernatants, namely control, GOSS-treated (6.25 $\mu \mathrm{M}$ in MM-231 cells and $5 \mu \mathrm{M}$ in MM-468 cells), $50 \mathrm{ng} / \mathrm{ml} \mathrm{TNF-} \alpha$-stimulated, and co-treated cells (TNF- $\alpha+$ GOSS). The data are presented as the mean \pm SEM of three independent experiments. The dot intensities are expressed as percent relative to control. The significant difference between TNF- $\alpha$-stimulated cells vs. resting cells $(*)$ or between TNF- $\alpha$-stimulated vs. TNF- $\alpha+$ GOSS-treated cells (\#) groups was determined by an unpaired t-test. P $<0.05$ was considered to indicate a statistically significant difference. ${ }^{* *} \mathrm{P}<0.01,{ }^{* * * *} \mathrm{P}<0.001,{ }^{\# \#} \mathrm{P}<0.01$ and ${ }^{\# \# \#} \mathrm{P}<0.001$. NS, not significant; GOSS, gossypol; TNF- $\alpha$, tumor necrosis factor $\alpha$.
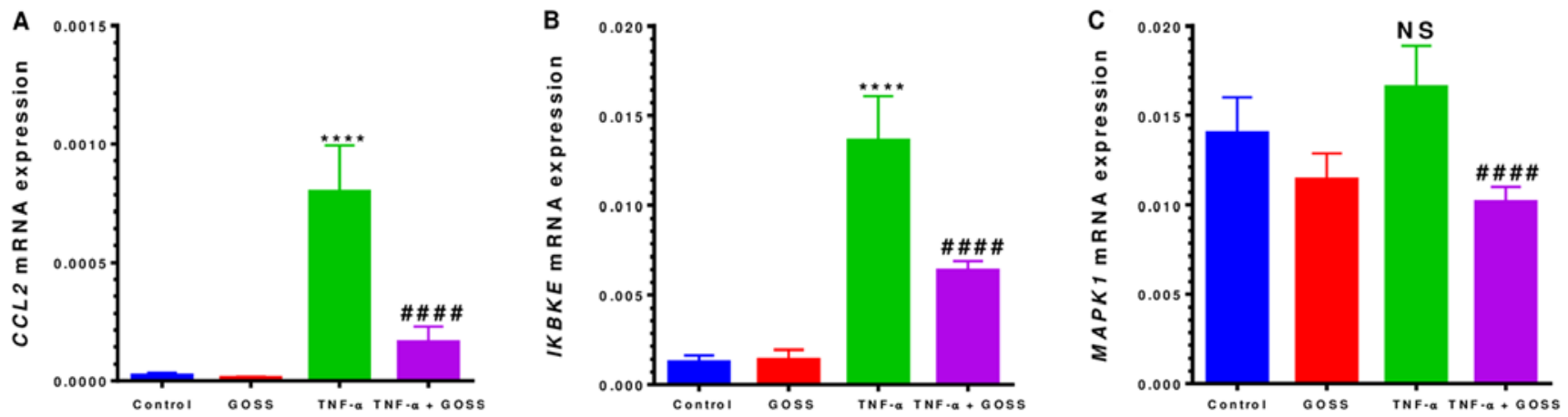

Figure 5. Effect of GOSS on proinflammatory cytokine-related gene expression determined using reverse transcription-quantitative PCR in TNF- $\alpha$-stimulated MM-231 cells. GAPDH-normalized data indicated a significant increase in (A) CCL2 and (B) IKBKE mRNA expression in TNF- $\alpha$-stimulated MM-231 cells compared with control cells. The same genes, as well as (C) MAPKl, were significantly inhibited in the presence of $6.25 \mu \mathrm{M} \mathrm{GOSS}$. The data points are presented as the mean \pm SEM of three independent experiments. The significance of the difference was analyzed by an unpaired t-test. $\mathrm{P}<0.05$ was considered to indicate a statistically significant difference. ${ }^{* * * * *} \mathrm{P}<0.0001$ vs. control; ${ }^{\# \# \# \#} \mathrm{P}<0.0001$ vs. TNF- $\alpha$. NS, not significant; GOSS, gossypol; TNF- $\alpha$, tumor necrosis factor $\alpha$. 
A

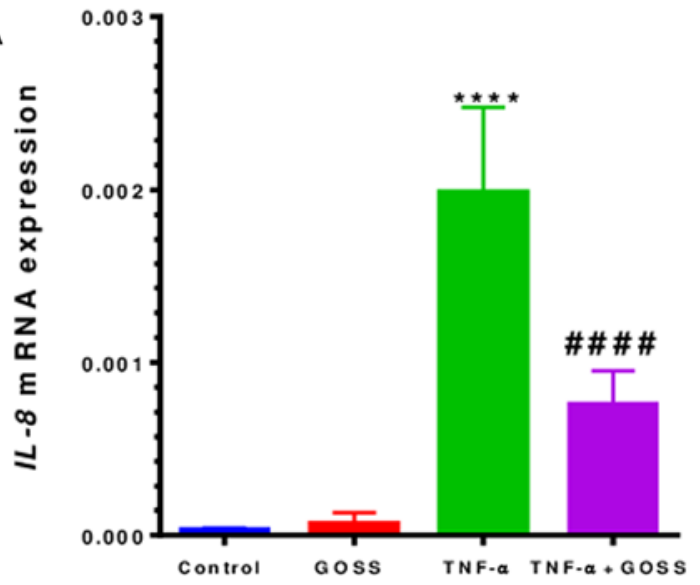

C

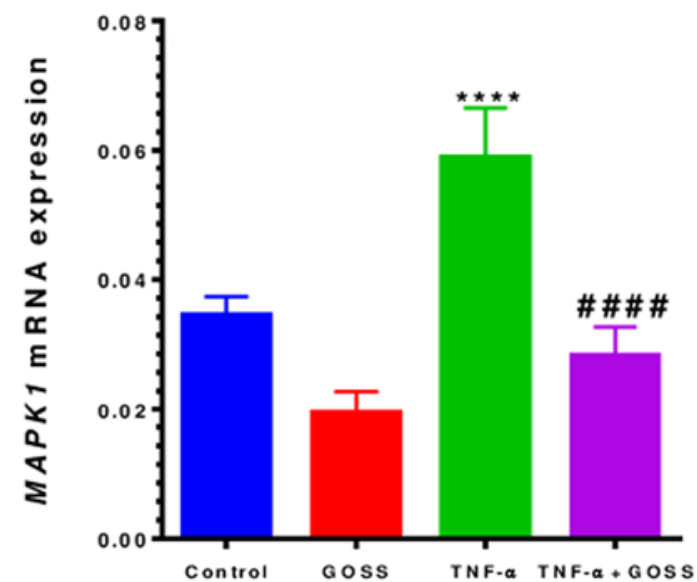

E

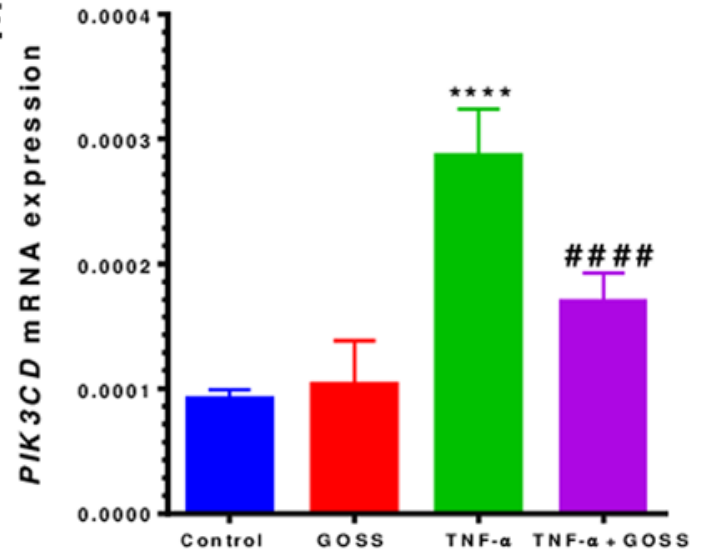

B

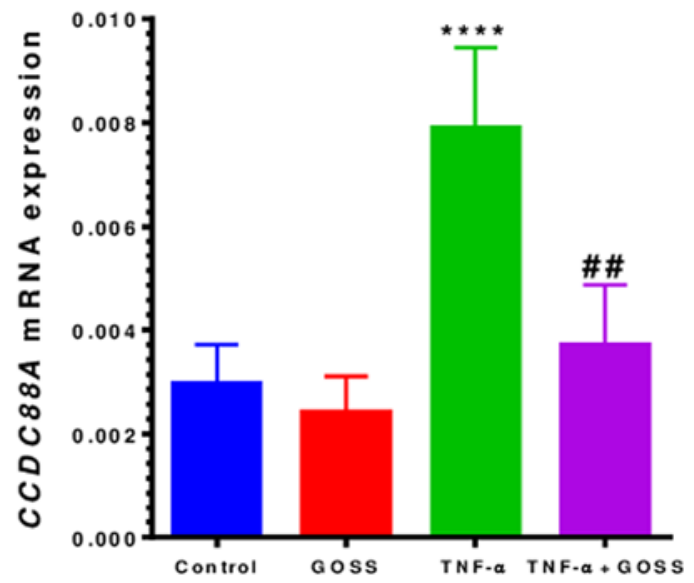

D

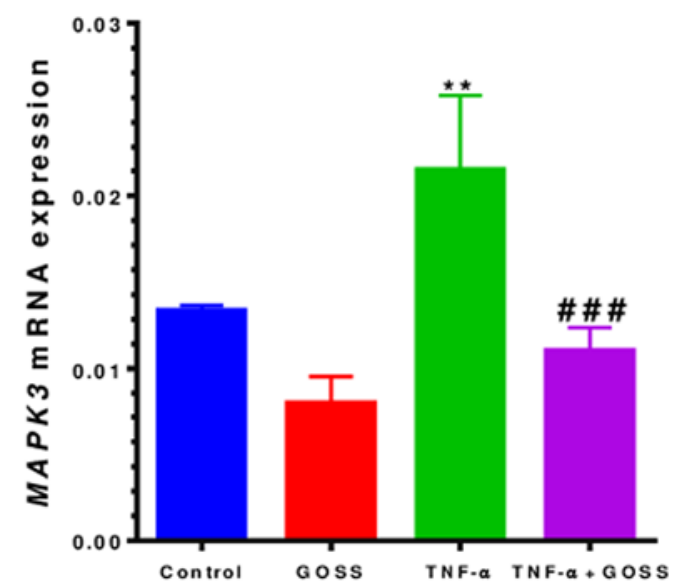

$\mathbf{F}$

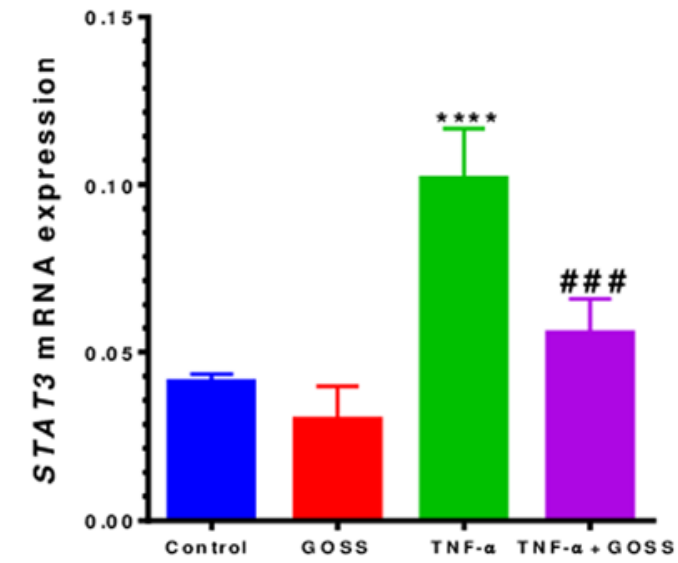

Figure 6. Effect of GOSS on proinflammatory cytokine-related gene expression in TNF- $\alpha$-stimulated MM-468 cells according to reverse transcription-quantitative PCR. GAPDH-normalized data indicated a significant increase in six genes in TNF- $\alpha$-stimulated vs. control cells as follows: (A) IL-8, (B) CCDC88A, (C) MAPK1, (D) MAPK3, (E) PIK3CD and (F) STAT3 genes. The same genes were significantly inhibited in the presence of $5 \mu$ M GOSS. The data points are presented as the mean \pm SEM of three independent experiments. The significance of the difference between TNF- $\alpha$-stimulated vs. control cells as well as TNF- $\alpha$-activated vs. TNF- $\alpha+$ GOSS was analyzed by an unpaired t-test. $\mathrm{P}<0.05$ was considered to indicate a statistically significant difference. ${ }^{* *} \mathrm{P}<0.01$ and ${ }^{* * * *} \mathrm{P}<0.0001$ vs. control; ${ }^{\# \#} \mathrm{P}<0.01,{ }^{\# \#} \mathrm{P}<0.001$ and ${ }^{\# \# \# \#} \mathrm{P}<0.0001$ vs. TNF- $\alpha$. GOSS, gossypol; TNF- $\alpha$, tumor necrosis factor $\alpha$.

have validated the up-regulation of CCL2 and IL-8 pro-inflammatory proteins and their mRNAs and assured GOSS ability to inhibit both of them.

\section{Discussion}

One of the significant goals in anticancer drug development is targeting signaling pathways regulating cancer cells' survival and proliferation through the inhibition of distinctive gene expressions. The present study examined the anticancer mechanism of the natural polyphenol GOSS in two racially different TNBC cell models. The cytotoxic effects of GOSS with a slight but significantly higher response against MM-231 cells than MM-468 TNBC cells indicate possible different mechanistic effects between the two cell lines. However, the effect of gossypol on normal breast cells was not established; a previous study on another cell line indicated the safety of the gossypol at a similar dose (53). This compound repressed the TNF- $\alpha$-mediated upregulation of the two BC-dominant proinflammatory chemokines (CCL2) in MM-231 and (IL-8) 
Table II. Gene expression changes in MM-231 triple-negative breast cancer.

Control vs. TNF- $\alpha$

TNF- $\alpha$ vs. TNF- $\alpha+$ GOSS

\begin{tabular}{|c|c|c|c|c|c|}
\hline Target gene & Fold (+) & P-value & Target gene & Inhibition (\%) & P-value \\
\hline$C C L 2$ & 32.72 & $<0.0001$ & CCL2 & 79.46 & $<0.0001$ \\
\hline$I K B K E$ & 10.60 & $<0.0001$ & $I K B K E$ & 53.06 & $<0.0001$ \\
\hline$M A P K 1$ & 1.18 & 0.0648 & $M A P K 1$ & 38.81 & $<0.0001$ \\
\hline
\end{tabular}

The left side of the table presents the genes that were upregulated (+ fold-changes) by $50 \mathrm{ng} / \mathrm{ml} \mathrm{TNF}-\alpha$. By contrast, the right side presents the expression of genes that were downregulated (\% inhibition) by $6.25 \mu \mathrm{M}$ GOSS. P $<0.05$ was considered to indicate a statistically significant difference. GOSS, gossypol; TNF- $\alpha$, tumor necrosis factor $\alpha$.

Table III. mRNA gene expression changes in MM-468 triple-negative breast cancer.

Control vs. TNF- $\alpha$

\begin{tabular}{|c|c|c|c|c|c|}
\hline Target gene & Fold (+) & P-value & Target gene & Inhibition (\%) & P-value \\
\hline$I L-8$ & 64.6 & $<0.0001$ & $I L-8$ & 60.78 & $<0.0001$ \\
\hline$C C D C 88 A$ & 2.66 & $<0.0001$ & $C C D C 88 A$ & 53.04 & 0.0013 \\
\hline$M A P K 1$ & 1.70 & $<0.0001$ & $M A P K 1$ & 51.90 & $<0.0001$ \\
\hline$M A P K 3$ & 1.61 & 0.0062 & MAPK3 & 48.61 & 0.0002 \\
\hline$P I K 3 C D$ & 3.12 & $<0.0001$ & PIK3CD & 40.70 & $<0.0001$ \\
\hline STAT3 & 2.47 & $<0.0001$ & STAT3 & 45.28 & $<0.0001$ \\
\hline
\end{tabular}

The left side of the table presents the genes that are upregulated (+ fold-changes) by $50 \mathrm{ng} / \mathrm{ml}$ TNF- $\alpha$. By contrast, the right side presents the expression of genes that are downregulated (\% inhibition) by $5 \mu \mathrm{M}$ GOSS. $\mathrm{P}<0.05$ was considered to indicate a statistically significant difference. GOSS, gossypol; TNF- $\alpha$, tumor necrosis factor $\alpha$.

in MM-468. Mechanisms of inhibitions involved the attenuation of mRNA expression of divers, active genes crucial in regulating pivotal signaling pathways. GOSS impacted MAPK, JAK-STAT, and NF-қB pathways in both cell lines, in addition to the PI3K-AKT pathway only in MM-468 (Fig. 7).

The high expression of TNF- $\alpha$ has been reported in $\mathrm{BC}$ patients (21). Whether it is endogenous or is administered in a high dose, TNF- $\alpha$ can function as tumor necrosis or tumor-promoting factor, respectively (54). In cancer, the highly expressed TNF- $\alpha$ stimulates the release of many chemokines, including CCL2 and IL-8 (5,55-57), that are highly expressed in cancer.

The most attenuated chemokines, CCL2, and IL- 8 have been known to share some common characters. Both chemokines are belonging to a superfamily of small, soluble, and secreted proteins (58). They both are released into the cancer microenvironment by the endothelial cells and fibroblasts $(59,60)$ to activate lymphocytes and macrophages $(61,62)$.

Treating MM-231 cells with TNF- $\alpha$ upregulated the expression of CCL2, a finding that is consistent with previous studies $(17,63)$. In the presence of GOSS (low dose of $6.25 \mu \mathrm{M})$, CCL2 expression was dramatically downregulated in the TNF- $\alpha$-activated cells. Cytokine CCL2 is the most cancer-related member of the CC chemokine family (64). In $\mathrm{BC}$ cells, upregulated CCL2 (65) promotes tumorigenesis and metastasis, and its suppression significantly reduced tumor aggressiveness (66). In MM-231 and other malignant tumors, the upregulated CCL2 $(51,59)$ was linked to the decreased survival of TNBC patients (6). Hence, the reduction of CCL2 expression following antibody administration or genetic mutation (67) led to reduced metastasis and enhanced survival (51), which hold promise in treating TNBC (6).

Previous investigations have highlighted the impact of CCL2 on different signaling pathways regulation. CCL2 and its main receptor CCR2 control BC cell survival through MAPK- and Smad3-dependent mechanisms (19). Moreover, in various tissues, CCL2 activates Notch signaling pathway and regulates cancer stem cells (68), which are vital for BC progression (69,70). CCL2 gene silencing in MM-231 led to various consequences, including inhibition of CCL2 expression, decreased cell proliferation, increased necrosis and autophagy, inhibition of self-renewal, and inhibition of the primary and secondary invasion of the TNBC xenograft tumor, and decreases M2 macrophage recruitment (6).

Our current RT-qPCR gene expression analyses indicate that TNF- $\alpha$ significantly increased the mRNA expression of two genes: CCL2 and its gene regulator IKBKE. At the same time, the data obtained show the ability of GOSS to attenuate the expression of these two genes as well as MAPK1. These three genes are involved in many signaling pathways, 


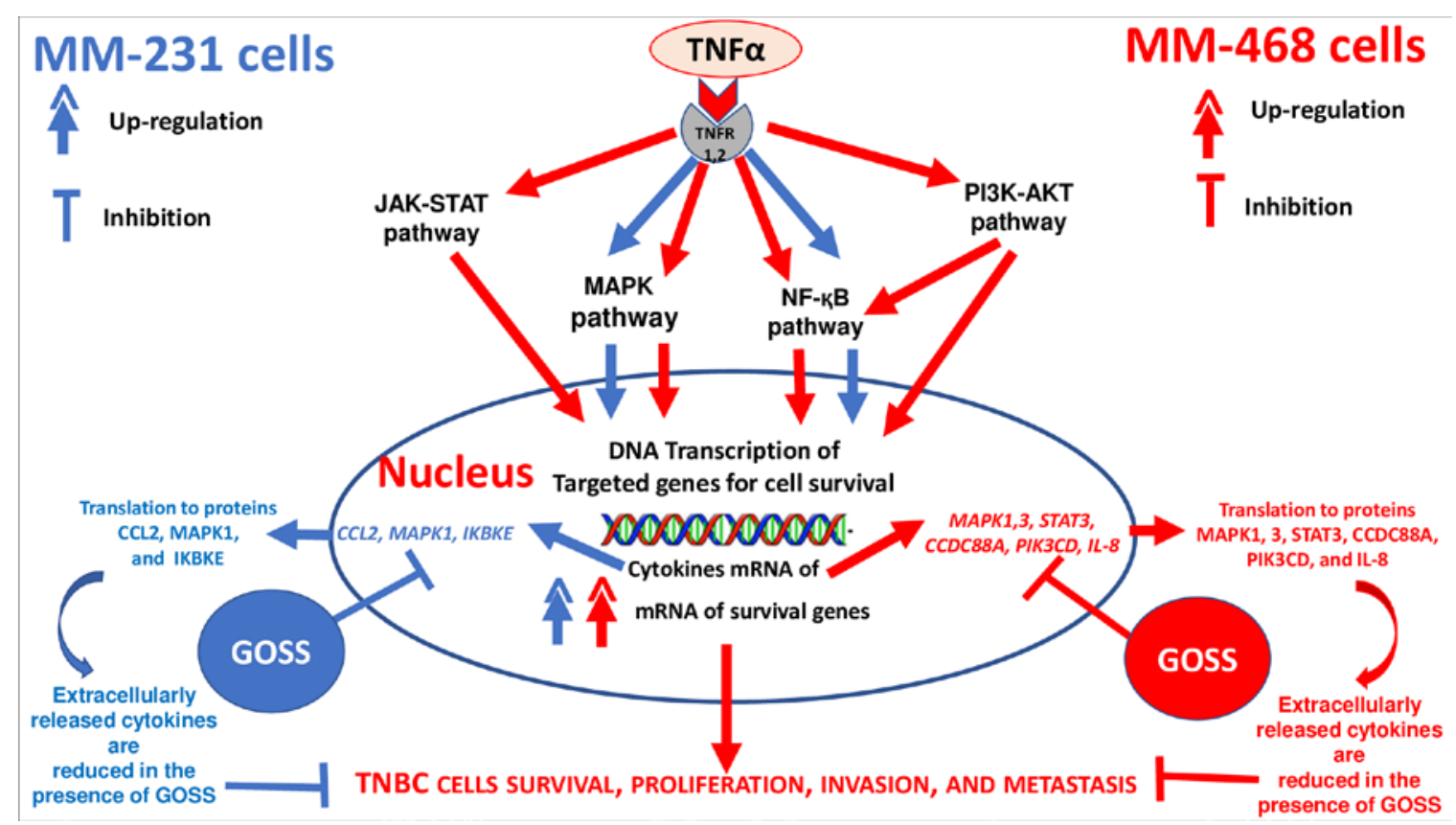

Figure 7. Schematic diagram illustrating pro-inflammatory genes involved in different signaling pathways that mediate the release of CCL2 and IL-8 in TNF- $\alpha$-stimulated MM-231 (blue color) and MM-468 (red color) triple-negative breast cancer cells, respectively. In MM-231 cells, the most down-regulated genes by GOSS are CCL2, IKBKE, and MAPK1. In MM-468 cells, the most down-regulated genes are $I L-8, C C D C 88 A, M A P K 1$ and 3,PIK3CD, and STAT3 GOSS, gossypol; TNF- $\alpha$, tumor necrosis factor $\alpha$.

including the NF-қB, JAK-STAT, and MAPK, which regulate the expression of CCL2. Nevertheless, NF-қB and MAPK signaling pathways are used by both normal and cancer cells dominating these signaling pathways to enhance their survival and invasion (71).

The gene $I K B K E$ (also known as IKKe) is a member of the IKK family of kinases (72). Extensive studies have reported the correlation between $I K B K E$ down-regulation and the decrease of CCL2 release $(49,73)$. Our current data supported these previous findings and interpreted the mechanism of CCL2 inhibition by GOSS. In TNBC cells, the $I K B K E$ gene is expressed in $60 \%$ of $\mathrm{BC}$ tissue (74) and acts as an oncogene to support cell viability. Furthermore, the up-regulation of $I K B K E$ enhances resistance to anticancer drugs and protects the BC cells from Tamoxifen-induced apoptosis (75). Indeed, $I K B K E$ is an upstream regulator of the transcription factor NF-kB and JAK-STAT pathways, which have been actively involved in the pathogenesis of TNBC (76-79). Expectedly, the silencing of IKBKE in BC cells has been reported to reduce the NF-қB activity and inhibit proliferation, clonogenicity, migration, and invasion (80-84).

GOSS inhibited the expression of MAPK1 (also known as $E R K$ ) that was highly expressed in unstimulated cells. The obtained data are consistent with those from previous studies $(85,86)$ that related the lower survival rate in TNBC to highly expressed $M A P K s$. These serine/threonine protein kinases are involved in various intracellular metabolism, including differentiation, proliferation, apoptosis, and cellular stress responses $(87,88)$. Deregulated ERK signaling pathway leads to uncontrolled cell proliferation and a reduction in apoptosis (89). In MM-231 BC cells, upregulated p38 pathway is linked to the increased proliferation and migration (71) and contribute to cancer cell invasion (90). Therefore, highlighting GOSS effects on MAPKs implies its particularity for TNBC.

Our data indicated that TNF- $\alpha$-stimulated the release of IL-8 In MM-468 cells, the finding that agrees with a previous study (56). Indeed, a significant positive relationship has been reported between IL- 8 release and TNF- $\alpha$ that can synergistically affect cancer initiation and progression (55). The double-functional IL-8 can boost the immunoregulatory ability or alter the cell microenvironment to enhance tumorigenesis (91). The chemokine IL- 8 is a member of the CXC chemokine family of multi-functional proinflammatory cytokines (92). IL-8 is highly expressed in many types of tumors and has the ability to promote cancer cell proliferation (93). In BC patients, elevated levels of serum IL-8 is a predictive marker $(55,94)$. Moreover, IL- 8 is positively correlated with angiogenesis and metastasis (95) and contributes to multidrug resistance in human BC cells (96). Particularly in TNBC, IL-8 is highly expressed compared with other BC subtypes (97), and it is associated with a poor prognosis $(55,92,98)$. Meaningfully, the poorer prognosis and treatment resistance are linked to IL-8 and its highly expressed receptors, CXCR1 (IL-8R ${ }_{\mathrm{A}}$ ) and CXCR2 $\left(\mathrm{IL}_{-} 8 \mathrm{R}_{\mathrm{B}}\right)$ in BC patients $(95,99,100)$. Therefore, targeting CXCR signaling is considered a promising approach in in-vivo models of $\mathrm{BC}$ (101) as it attenuates the distress effect of IL-8 (102). Here, the TNF- $\alpha$-stimulated IL- 8 expression was followed by a substantial attenuation of the chemokine in the presence of only $5 \mu \mathrm{M}$ of GOSS.

In MM-468 cells, GOSS repressed many highly expressed genes, including IL-8, MAPK1, MAPK3, CCDC88A, STAT3, and $P I K 3 C D$. The number and type of the affected genes in MM-468 were divergent from its counterpart mRNA data for MM-231. The repressed genes modulate major signaling pathways, including MAPK, PI3K-AKT, JAK-STAT, and 
NF-қB. Those oncogenic signaling pathways regulate IL-8 expression and potentiate tumor cell migration or invasion $(103,104)$. The data indicated high expressions of $M A P K 1$ and $M A P K 3$ in unstimulated MM-468 cells; an observation which is consistent with its counterpart MM-231 and agrees with those previously reported findings $(85,86)$. The reported link between $I L-8 \mathrm{mRNA}$ stabilization, its protein production, and the MAPKs (105-107) is compatible with GOSS effects in our MM-468 study.

Furthermore, GOSS inhibited the expression of the CCDC88A gene [also known as AKT phosphorylation enhancer (APE), or AKT-binding protein Girdin], that is highly expressed in BC and other types of cancer (108). The gene augmenting the PI3K-AKT signaling pathway and regulate cell migration (109), proliferation, and apoptosis (110). Also, upregulated AKT expression enhances the NF-қB signaling pathway, promoting tumor progression and metastasis (111). GOSS repressed the overexpression of $P I K 3 C D$, the gene encoding phosphoinositide 3 -kinase $(P I 3 K)$. The activated $P I 3 K$ signaling is involved in metabolism and is essential in promoting tumorigenesis and cell proliferation (112-114). In normal cells, PI3K-AKt/mTOR signaling pathways are critical for cell survival and proliferation. Meanwhile, PI3K, AKT, and mTOR proteins are highly upregulated in BC and other cancers. Inhibitors of these kinases are found to induce apoptosis and to synergize the effect of anticancer drugs to inhibit the tumor progression (112-114). Thus, the obtained data indicate GOSS targeting ability of both PIK3CD and CCDC $88 A$ by indirectly attenuating $\mathrm{NF}_{\mathrm{B}} \mathrm{B}$ and, consequently, the overexpression of IL-8 in MM-468 BC cells. The mRNA expression inhibition of the signal transducer and activator of transcription3 (STAT3) signifies the GOSS role against BC. STAT3 is a member of the STAT family proteins, and it is highly triggered in more than $50 \%$ of BC patients (115). Furthermore, Targeting STAT3 impacts other cancer-associated pro-inflammatory cytokines (116) and many genes linked to apoptosis, proliferation, and angiogenesis (117). Moreover, phosphorylation of STAT3, AKT, and ERK1/2 stimulate BC cells to undergo epithelial-mesenchymal transition, up-regulate the expression of IL-8 and stimulate BC metastasis (104), inhibiting the mRNA expressions of these proteins in MM-468 cells may further elucidate previously reported anticancer mechanisms of GOSS through inhibiting their phosphorylation (37). Thus, inhibiting STAT3 activation by GOSS is a substantial target in treating different types of cancer.

In summary, the comparative effect of gossypol on different cytokines release from TNBC cells has never been reported before. Also, gossypol effects on the aggressive TNBC of MM-468 cells, derived from AA women (118), are not reported. The current study elucidated a novel mechanism targeting TNBC and highlight the possible gene-related signaling pathways. However, lacking protein production assessments, such as using Western blotting, is a limitation in this research and needs further broader range investigation. The polyphenol compound, GOSS, impacts MM-231 and MM-468 cells differently. In MM-231 cells, the compound attenuated the expression of the cytokine CCL2 through influencing its encoding gene, $C C L 2$, as well as two more regulatory genes (IKBKE and $M A P K 1)$, which are involved in NF-қB, JAK-STAT, and MAPK signaling pathways. Similarly,
GOSS repressed the cytokine IL- 8 in MM-468 cells by targeting IL-8 mRNA expression. However, more genes were inhibited by GOSS, including $M A P K 1, M A P K 3, P I K 3 C D$, $S T A T 3$, and $C C D C 88 A$. These genes are regulating different interactive signaling pathways mediating IL-8 releases such as PI3K-AKT, JAK-STAT, and MAPK. In conclusion, the data obtained in this study indicate that the polyphenol compound GOSS may provide a valuable tool in TNBC therapies.

\section{Acknowledgements}

Not applicable.

\section{Funding}

The present study was supported by the National Institute of Minority Health and Health Disparity (grant nos. U54 MD007582 and P20 MD006738).

\section{Availability of data and materials}

All data generated or analyzed during this study are included in this published article.

\section{Authors' contributions}

The conceptualization of this study was accomplished by SSM and KFAS. The research methodology was designed by SSM, NOZ, PM, CC and KFAS. Data analysis was conducted by SSM, NOZ, PM, CC and KFAS. Funding acquisition was fulfilled by KFAS. Project administration was performed by KFAS, and study resources were collected by SSM, NOZ, PM, CC and KFAS. Software analysis of data and figures was conducted by SSM, NOZ, PM and CC, and supervision of the research was conducted by KFAS. Writing of the original draft was undertaken by SSM, and writing, review, and editing of the manuscript were carried out by SSM, NOZ, PM and KFAS. All authors read and approved the final manuscript and accept to be responsible for all aspects of the research in ensuring that the accuracy or integrity of any part of the work is properly considered.

\section{Ethics approval and consent to participate}

Not applicable.

\section{Patient consent for publication}

Not applicable.

\section{Competing interests}

The authors declare that they have no competing interests.

\section{References}

1. Coussens LM and Werb Z: Inflammation and cancer. Nature 420: 860-867, 2002

2. Aggarwal BB: Nuclear factor-kappaB: The enemy within. Cancer Cell 6: 203-208, 2004

3. Balkwill $\mathrm{F}$ and Mantovani A: Inflammation and cancer: Back to virchow? Lancet 357: 539-545, 2001 
4. Kuper H, Adami HO and Trichopoulos D: Infections as a major preventable cause of human cancer. J Intern Med 248: 171-183, 2000.

5. Balkwill F: TNF-alpha in promotion and progression of cancer. Cancer Metastasis Rev 25: 409-416, 2006.

6. Fang WB, Yao M, Brummer G, Acevedo D, Alhakamy N, Berkland $C$ and Cheng N: Targeted gene silencing of CCL2 inhibits triple negative breast cancer progression by blocking cancer stem cell renewal and M2 macrophage recruitment. Oncotarget 7: 49349-49367, 2016.

7. Sørlie T, Perou CM, Tibshirani R, Aas T, Geisler S, Johnsen H, Hastie T, Eisen MB, van de Rijn M, Jeffrey SS, et al: Gene expression patterns of breast carcinomas distinguish tumor subclasses with clinical implications. Proc Natl Acad Sci USA 98: 10869-10874, 2001.

8. Niemeier LA, Dabbs DJ, Beriwal S, Striebel JM and Bhargava R: Androgen receptor in breast cancer: Expression in estrogen receptor-positive tumors and in estrogen receptor-negative tumors with apocrine differentiation. Mod Pathol 23: 205-212, 2010.

9. Anders CK and Carey LA: Biology, metastatic patterns, and treatment of patients with triple-negative breast cancer. Clin Breast Cancer 2 (Suppl 2): S73-S81, 2009.

10. Albain KS, Unger JM, Crowley JJ, Coltman CA Jr and Hershman DL: Racial disparities in cancer survival among randomized clinical trials patients of the Southwest oncology group. J Natl Cancer Inst 101: 984-992, 2009.

11. Beaumont $\mathrm{T}$ and Leadbeater M: Treatment and care of patients with metastatic breast cancer. Nurs Stand 25: 49-56, 2011.

12. Fernandez Y, Cueva J, Palomo AG, Ramos M, de Juan A, Calvo L, García-Mata J, García-Teijido P, Peláez I and García-Estévez L: Novel therapeutic approaches to the treatment of metastatic breast cancer. Cancer Treat Rev 36: 33-42, 2010.

13. Liu P, Kumar IS, Brown S, Kannappan V, Tawari PE, Tang JZ, Jiang W, Armesilla AL, Darling JL and Wang W: Disulfiram targets cancer stem-like cells and reverses resistance and cross-resistance in acquired paclitaxel-resistant triple-negative breast cancer cells. Br J Cancer 109: 1876-1885, 2013.

14. Craig DW, O'Shaughnessy JA, Kiefer JA, Aldrich J, Sinari S, Moses TM, Wong S, Dinh J, Christoforides A, Blum JL, et al: Genome and transcriptome sequencing in prospective metastatic triple-negative breast cancer uncovers therapeutic vulnerabilities. Mol Cancer Ther 12: 104-116, 2013.

15. Allavena P, Garlanda C, Borrello MG, Sica A and Mantovani A: Pathways connecting inflammation and cancer. Curr Opin Genet Dev 18: 3-10, 2008.

16. Candido $\mathrm{J}$ and Hagemann T: Cancer-related inflammation. J Clin Immunol 33 (Suppl 1): S79-S84, 2013

17. Saji H, Koike M, Yamori T, Saji S, Seiki M, Matsushima K and Toi M: Significant correlation of monocyte chemoattractant protein-1 expression with neovascularization and progression of breast carcinoma. Cancer 92: 1085-1091, 2001.

18. Bieche I, Chavey C, Andrieu C, Busson M, Vacher S, Corre LL, Guinebretière JM, Burlinchon S, Lidereau R and Lazennec G: CXC chemokines located in the $4 \mathrm{q} 21$ region are up-regulated in breast cancer. Endocr Relat Cancer 14: 1039-1052, 2007.

19. Fang WB, Jokar I, Zou A, Lambert D, Dendukuri P and Cheng N: CCL2/CCR2 chemokine signaling coordinates survival and motility of breast cancer cells through Smad3 protein- and p42/44 mitogen-activated protein kinase (MAPK)-dependent mechanisms. J Biol Chem 287: 36593-36608, 2012.

20. Perrot-Applanat M, Vacher S, Toullec A, Pelaez I, Velasco G, Cormier F, El Sheikh Saad H, Lidereau R, Baud V and Bièche I: Similar NF-kB gene signatures in TNF- $\alpha$ treated human endothelial cells and breast tumor biopsies. PLoS One 6: e21589, 2011.

21. Leek RD, Landers R, Fox SB, Ng F, Harris AL and Lewis CE: Association of tumour necrosis factor alpha and its receptors with thymidine phosphorylase expression in invasive breast carcinoma. Br J Cancer 77: 2246-2251, 1998.

22. Wang N, Liang $\mathrm{H}$ and Zen $\mathrm{K}$ : Molecular mechanisms that influence the macrophage m1-m2 polarization balance. Front Immunol 5: 614, 2014.

23. Yin Y, Chen X and Shu Y: Gene expression of the invasive phenotype of TNF-alpha-treated MCF-7 cells. Biomed Pharmacother 63: 421-428, 2009.

24. Voss V, Senft C, Lang V, Ronellenfitsch MW, Steinbach JP, Seifert V and Kögel D: The pan-Bcl-2 inhibitor (-)-gossypol triggers autophagic cell death in malignant glioma. Mol Cancer Res 8: 1002-1016, 2010.

25. Bromberg J: Stat proteins and oncogenesis. J Clin Invest 109: $1139-1142,2002$.
26. Dreesen $\mathrm{O}$ and Brivanlou AH: Signaling pathways in cancer and embryonic stem cells. Stem Cell Rev 3: 7-17, 2007.

27. Zubair A and Frieri M: Role of nuclear factor-kB in breast and colorectal cancer. Curr Allergy Asthma Rep 13: 44-49, 2013.

28. Zhong S, Leong J, Ye W, Xu P, Lin SH, Liu JY and Lin YC: (-)-Gossypol-enriched cottonseed oil inhibits proliferation and adipogenesis of human breast pre-adipocytes. Anticancer Res 33: 949-955, 2013

29. Cao H, Sethumadhavan K and Bland JM: Isolation of cottonseed extracts that affect human cancer cell growth. Sci Rep 8: 10458, 2018.

30. He Z, Zhang H and Olk DC: Chemical composition of defatted cottonseed and soy meal products. PLoS One 10: e0129933, 2015.

31. Sharifi-Rad M, Fokou PVT, Sharopov F, Martorell M, Ademiluyi AO, Rajkovic J, Salehi B, Martins N, Iriti M and Sharifi-Rad J: Antiulcer agents: From plant extracts to phytochemicals in healing promotion. Molecules 23: 1751, 2018.

32. Wang X, Howell CP, Chen F, Yin J and Jiang Y: Gossypol-a polyphenolic compound from cotton plant. Adv Food Nutr Res 58: 215-263, 2009.

33. Zhang M, Liu H, Guo R, Ling Y, Wu X, Li B, Roller PP, Wang S and Yang D: Molecular mechanism of gossypol-induced cell growth inhibition and cell death of HT-29 human colon carcinoma cells. Biochem Pharmacol 66: 93-103, 2003.

34. Pang X, Wu Y, Wu Y, Lu B, Chen J, Wang J, Yi Z, Qu W and Liu M: (-)-Gossypol suppresses the growth of human prostate cancer xenografts via modulating VEGF signaling-mediated angiogenesis. Mol Cancer Ther 10: 795-805, 2011.

35. Flack MR, Pyle RG, Mullen NM, Lorenzo B, Wu YW, Knazek RA, Nisula BC and Reidenberg MM: Oral gossypol in the treatment of metastatic adrenal cancer. J Clin Endocrinol Metab 76: 1019-1024, 1993.

36. Moon DO, Kim MO, Lee JD and Kim GY: Gossypol suppresses NF-kappaB activity and NF-kappaB-related gene expression in human leukemia U937 cells. Cancer Lett 264: 192-200, 2008.

37. Benvenuto M, Mattera R, Masuelli L, Taffera G, Andracchio O, Tresoldi I, Lido P, Giganti MG, Godos J, Modesti A and Bei R: $( \pm)$-Gossypol induces apoptosis and autophagy in head and neck carcinoma cell lines and inhibits the growth of transplanted salivary gland cancer cells in BALB/c mice. Int J Food Sci Nutr 68: 298-312, 2017.

38. Moon DO, Choi YH, Moon SK, Kim WJ and Kim GY: Gossypol decreases tumor necrosis factor- $\alpha$-induced intercellular adhesion molecule-1 expression via suppression of NF- $\mathrm{KB}$ activity. Food Chem Toxicol 49: 999-1005, 2011.

39. Gilbert NE, O'Reilly JE, Chang CJ,Lin YC and BrueggemeierRW: Antiproliferative activity of gossypol and gossypolone on human breast cancer cells. Life Sci 57: 61-67, 1995.

40. Hu YF, Chang CJ, Brueggemeier RW and Lin YC: Gossypol inhibits basal and estrogen-stimulated DNA synthesis in human breast carcinoma cells. Life Sci 53: PL433-PL438, 1993.

41. Chou TC: Drug combination studies and their synergy quantification using the Chou-Talalay method. Cancer Res 70: 440-446, 2010.

42. Yoshida R, Niki M, Jyotaki M, Sanematsu K, Shigemura N and Ninomiya Y: Modulation of sweet responses of taste receptor cells. Semin Cell Dev Biol 24: 226-231, 2013.

43. Cheng W, Zhao YQ, Li YM and Yang DJ: Effects of gossypol acetate on apoptosis in primary cultured cells from patients with lymphoid leukemia and its synergy with dexamethasone. Zhongguo Shi Yan Xue Ye Xue Za Zhi 20: 229-234, 2012 (In Chinese).

44. Baoleri X, Dong C, Zhou Y, Zhang Z, Lu X, Xie P and Li Y: Combination of L-gossypol and low-concentration doxorubicin induces apoptosis in human synovial sarcoma cells. Mol Med Rep 12: 5924-5932, 2015.

45. Karaca B, Atmaca H, Uzunoglu S, Karabulut B, Sanli UA and Uslu R: Enhancement of taxane-induced cytotoxicity and apoptosis by gossypol in human breast cancer cell line MCF-7. J BUON 14: 479-485, 2009.

46. Zhao GX, Xu LH, Pan H, Lin QR, Huang MY, Cai JY, Ouyang DY and He XH: The BH3-mimetic gossypol and noncytotoxic doses of valproic acid induce apoptosis by suppressing cyclin-A2/Akt/FOXO3a signaling. Oncotarget 6: 38952-38966, 2015.

47. Tate CR, Rhodes LV, Segar HC, Driver JL, Pounder FN, Burow ME and Collins-Burow BM: Targeting triple-negative breast cancer cells with the histone deacetylase inhibitor panobinostat. Breast Cancer Res 14: R79, 2012. 
48. Sato N, Beitz JG, Kato J, Yamamoto M, Clark JW, Calabresi P, Raymond A and Frackelton Jr AR: Platelet-derived growth factor indirectly stimulates angiogenesis in vitro. Am J Pathol 142: $1119-1130,1993$

49. Messeha SS, Zarmouh NO, Mendonca P, Alwagdani H, Kolta MG and Soliman KFA: The inhibitory effects of plumbagin on the NF-kB pathway and CCL2 release in racially different triple-negative breast cancer cells. PLoS One 13: e0201116, 2018

50. Livak KJ and Schmittgen TD: Analysis of relative gene expression data using real-time quantitative PCR and the 2(-Delta Delta C(T)) method. Methods 25: 402-408, 2001.

51. Yamamoto H, Omelchenko I, Shi X and Nuttall AL: The influence of NF-kappaB signal-transduction pathways on the murine inner ear by acoustic overstimulation. J Neurosci Res 87 : 1832-1840, 2009.

52. Gallelli L, Falcone D, Cannataro R, Perri M, Serra R, Pelaia G, Maselli R, Savino R, Spaziano G and D'Agostino B: Theophylline action on primary human bronchial epithelial cells under proinflammatory stimuli and steroidal drugs: A therapeutic rationale approach. Drug Des Dev Ther 11: 265-272, 2017.

53. Barba-Barajas M, Hernandez-Flores G, Lerma-Diaz JM, Ortiz-Lazareno PC, Domínguez-Rodríguez JR, Barba-Barajas L, de Celis R, Jave-Suarez LF, Aguilar-Lemarroy AC, Guevara-Barraza MG and Bravo-Cuellar A: Gossypol induced apoptosis of polymorphonuclear leukocytes and monocytes: Involvement of mitochondrial pathway and reactive oxygen species. Immunopharmacol Immunotoxicol 31: 320-330, 2009.

54. Anderson GM, Nakada MT and DeWitte M: Tumor necrosis factor-alpha in the pathogenesis and treatment of cancer. Curr Opin Pharmacol 4: 314-320, 2004

55. Ma Y, Ren Y, Dai ZJ, Wu CJ, Ji YH and Xu J: IL-6, IL-8 and TNF- $\alpha$ levels correlate with disease stage in breast cancer patients. Adv Clin Exp Med 26: 421-426, 2017.

56. John M, Au BT, Jose PJ, Lim S, Saunders M, Barnes PJ, Mitchell JA, Belvisi MG and Chung KF: Expression and release of interleukin- 8 by human airway smooth muscle cells: Inhibition by Th-2 cytokines and corticosteroids. Am J Respir Cell Mol Biol 18: 84-90, 1998.

57. Grund EM, Kagan D, Tran CA, Zeitvogel A, Starzinski-Powitz A, Nataraja S and Palmer SS: Tumor necrosis factor-alpha regulates inflammatory and mesenchymal responses via mitogen-activated protein kinase kinase, $\mathrm{p} 38$, and nuclear factor kappaB in human endometriotic epithelial cells. Mol Pharmacol 73: 1394-1404, 2008.

58. An J, Xue Y, Long M, Zhang G, Zhang J and Su H: Targeting CCR2 with its antagonist suppresses viability, motility and invasion by downregulating MMP-9 expression in non-small cel lung cancer cells. Oncotarget 8: 39230-39240, 2017.

59. Strieter RM, Wiggins R, Phan SH, Wharram BL, Showell HJ, Remick DC, Chensue SW and Kunkel SL: Monocyte chemotactic protein gene expression by cytokine-treated human fibroblasts and endothelial cells. Biochem Biophys Res Commun 162 694-700, 1989.

60. Sticherling M, Hetzel F, Schroder JM and Christophers E: Timeand stimulus-dependent secretion of NAP-1/IL-8 by human fibroblasts and endothelial cells. J Invest Dermatol 101: 573-576, 1993.

61. Zachariae CO, Anderson AO, Thompson HL, Appella E, Mantovani A, Oppenheim JJ and Matsushima K: Properties of monocyte chemotactic and activating factor (MCAF) purified from a human fibrosarcoma cell line. J Exp Med 171: 2177-2182, 1990.

62. Krupa A, Fol M, Dziadek BR, Kepka E, Wojciechowska D, Brzostek A, Torzewska A, Dziadek J, Baughman RP, Griffith D and Kurdowska AK: Binding of CXCL8/IL-8 to mycobacterium tuberculosis modulates the innate immune response. Mediators Inflamm 2015: 124762, 2015.

63. Ueno T, Toi M, Saji H, Muta M, Bando H, Kuroi K, Koike M, Inadera $\mathrm{H}$ and Matsushima K: Significance of macrophage chemoattractant protein-1 in macrophage recruitment, angiogenesis, and survival in human breast cancer. Clin Cancer Res 6 : 3282-3289, 2000.

64. Matsushima K, Larsen CG, DuBois GC and Oppenheim JJ: Purification and characterization of a novel monocyte chemotactic and activating factor produced by a human myelomonocytic cell line. J Exp Med 169: 1485-1490, 1989.

65. Espinoza-Sanchez NA, Chimal-Ramirez GK, Mantilla A and Fuentes-Panana EM: IL-1 $\beta$, IL-8, and matrix metalloproteinases-1,-2, and -10 are enriched upon monocyte-breast cancer cell cocultivation in a matrigel-based three-dimensional system. Front Immunol 8: 205, 2017.
66. Nam JS, Kang MJ, Suchar AM, Shimamura T, Kohn EA, Michalowska AM, Jordan VC, Hirohashi S and Wakefield LM: Chemokine (C-C motif) ligand 2 mediates the prometastatic effect of dysadherin in human breast cancer cells. Cancer Res 66 : 7176-7184, 2006

67. Qian BZ, Li J, Zhang H, Kitamura T, Zhang J, Campion LR, Kaiser EA, Snyder LA and Pollard JW: CCL2 recruits inflammatory monocytes to facilitate breast-tumour metastasis. Nature 475: 222-225, 2011.

68. Tsuyada A, Chow A, Wu J, Somlo G, Chu P, Loera S, Luu T, Li XA, Wu X, Ye W, et al: CCL2 mediates cross-talk between cancer cells and stromal fibroblasts that regulates breast cancer stem cells. Cancer Res 72: 2768-2779, 2012.

69. Koury J, Zhong L and Hao J: Targeting signaling pathways in cancer stem cells for cancer treatment. Stem Cells Int 2017: $2925869,2017$.

70. Pires BR, DE Amorim ÍS, Souza LD, Rodrigues JA and Mencalha AL: Targeting cellular signaling pathways in breast cancer stem cells and its implication for cancer treatment. Anticancer Res 36: 5681-5691, 2016.

71. Huth HW, Santos DM, Gravina HD, Resende JM, Goes AM, de Lima ME and Ropert C: Upregulation of $\mathrm{p} 38$ pathway accelerates proliferation and migration of MDA-MB-231 breast cancer cells. Oncol Rep 37: 2497-2505, 2017.

72. Peters RT, Liao SM and Maniatis T: IKKepsilon is part of a novel PMA-inducible IkappaB kinase complex. Mol Cell 5: 513-522, 2000.

73. Bauer D, Redmon N, Mazzio E and Soliman KF: Apigenin inhibits $\mathrm{TNF} \alpha / \mathrm{IL}-1 \alpha$-induced CCL2 release through IKBK-epsilon signaling in MDA-MB-231 human breast cancer cells. PLoS One 12: e0175558, 2017.

74. Williams V, Grosset AA, Zamorano Cuervo N, St-Pierre Y, Sylvestre MP, Gaboury L and Grandvaux N: Detection of IKKepsilon by immunohistochemistry in primary breast cancer: Association with EGFR expression and absence of lymph node metastasis. BMC Cancer 17: 356, 2017.

75. Guo JP, Shu SK, Esposito NN, Coppola D, Koomen JM and Cheng JQ: IKK phosphorylation of estrogen receptor $\alpha$ Ser-167 and contribution to tamoxifen resistance in breast cancer. $\mathrm{J}$ Biol Chem 291: 22857, 2016.

76. Berishaj M, Gao SP, Ahmed S, Leslie K, Al-Ahmadie H, Gerald WL, Bornmann W and Bromberg JF: Stat3 is tyrosine-phosphorylated through the interleukin-6/glycoprotein 130/Janus kinase pathway in breast cancer. Breast Cancer Res 9: R32, 2007.

77. Li L and Shaw PE: Autocrine-mediated activation of STAT3 correlates with cell proliferation in breast carcinoma lines. J Biol Chem 277: 17397-17405, 2002

78. Walker SR, Nelson EA, Zou L, Chaudhury M, Signoretti S, Richardson A and Frank DA: Reciprocal effects of STAT5 and STAT3 in breast cancer. Mol Cancer Res 7: 966-976, 2009.

79. Marotta LL, Almendro V, Marusyk A, Shipitsin M, Schemme J, Walker SR, Bloushtain-Qimron N, Kim JJ, Choudhury SA, Maruyama R, et al: The JAK2/STAT3 signaling pathway is required for growth of CD44(+)CD24(-) stem cell-like breast cancer cells in human tumors. J Clin Invest 121: 2723-2735, 2011.

80. House CD, Grajales V, Ozaki M, Jordan E, Wubneh H, Kimble DC, James JM, Kim MK and Annunziata CM: IKKe cooperates with either MEK or non-canonical NF-kB driving growth of triple-negative breast cancer cells in different contexts. BMC Cancer 18: 595, 2018

81. Boehm JS, Zhao JJ, Yao J, Kim SY, Firestein R, Dunn IF, Sjostrom SK, Garraway LA, Weremowicz S, Richardson AL, et al: Integrative genomic approaches identify IKBKE as a breast cancer oncogene. Cell 129: 1065-1079, 2007.

82. Hutti JE, Shen RR, Abbott DW, Zhou AY, Sprott KM, Asara JM, Hahn WC and Cantley LC: Phosphorylation of the tumor suppressor CYLD by the breast cancer oncogene IKKepsilon promotes cell transformation. Mol Cell 34: 461-472, 2009.

83. Barbie TU, Alexe G, Aref AR, Li S, Zhu Z, Zhang X, Imamura Y, Thai TC, Huang Y, Bowden M, et al: Targeting an IKBKE cytokine network impairs triple-negative breast cancer growth. J Clin Invest 124: 5411-5423, 2014.

84. Qin B and Cheng K: Silencing of the IKKe gene by siRNA inhibits invasiveness and growth of breast cancer cells. Breast Cancer Res 12: R74, 2010.

85. Bartholomeusz C, Gonzalez-Angulo AM, Liu P, Hayashi N, Lluch A, Ferrer-Lozano J and Hortobágyi GN: High ERK protein expression levels correlate with shorter survival in triple-negative breast cancer patients. Oncologist 17: 766-774, 2012. 
86. Seddighzadeh M, Zhou JN, Kronenwett U, Shoshan MC, Auer G, Sten-Linder M, Wiman B and Linder S: ERK signalling in metastatic human MDA-MB-231 breast carcinoma cells is adapted to obtain high urokinase expression and rapid cell proliferation. Clin Exp Metastasis 17: 649-654, 1999.

87. Kyriakis JM and Avruch J: Mammalian MAPK signal transduction pathways activated by stress and inflammation: A 10-year update. Physiol Rev 92: 689-737, 2012.

88. Cargnello $M$ and Roux PP: Activation and function of the MAPKs and their substrates, the MAPK-activated protein kinases. Microbiol Mol Biol Rev 75: 50-83, 2011.

89. Samatar AA and Poulikakos PI: Targeting RAS-ERK signalling in cancer: Promises and challenges. Nat Rev Drug Discov 13: 928-942, 2014.

90. Wen S, Hou Y, Fu L, Xi L, Yang D, Zhao M, Qin Y, Sun K, Teng Y and Liu M: Cancer-associated fibroblast (CAF)-derived IL32 promotes breast cancer cell invasion and metastasis via integrin 33 -p38 MAPK signalling. Cancer Lett 442: 320-332, 2019

91. Liu Q, Li A, Tian Y, Wu JD, Liu Y, Li T, Chen Y, Han X and Wu K: The CXCL8-CXCR $1 / 2$ pathways in cancer. Cytokine Growth Factor Rev 31: 61-71, 2016.

92. Benoy IH, Salgado R, Van Dam P, Geboers K, Van Marck E, Scharpé S, Vermeulen PB and Dirix LY: Increased serum interleukin- 8 in patients with early and metastatic breast cancer correlates with early dissemination and survival. Clin Cancer Res 10: 7157-7162, 2004

93. Guo Y, Zang Y, Lv L, Cai F, Qian T, Zhang G and Feng Q: IL8 promotes proliferation and inhibition of apoptosis via STAT3/AKT/NFkB pathway in prostate cancer. Mol Med Rep 16: 9035-9042, 2017.

94. Snoussi K, Mahfoudh W, Bouaouina N, Ahmed SB, Helal AN and Chouchane L: Genetic variation in IL-8 associated with increased risk and poor prognosis of breast carcinoma. Hum Immunol 67: 13-21, 2006.

95.Zuccari DA, Leonel C, Castro R, Gelaleti GB, Jardim BV, Moscheta MG, Regiani VR, Ferreira LC, Lopes JR, Neto Dde S and Esteves JL: An immunohistochemical study of interleukin-8 (IL-8) in breast cancer. Acta Histochem 114: 571-576, 2012.

96. Kim S, Jeon M, Lee JE and Nam SJ: MEK activity controls IL-8 expression in tamoxifen-resistant MCF-7 breast cancer cells. Oncol Rep 35: 2398-2404, 2016.

97. Kim S, You D, Jeong Y, Yu J, Kim SW, Nam SJ and Lee JE: Berberine down-regulates IL-8 expression through inhibition of the EGFR/MEK/ERK pathway in triple-negative breast cancer cells. Phytomedicine 50: 43-49, 2018.

98. Yao C, Lin Y, Chua MS, Ye CS, Bi J, Li W, Zhu YF and Wang SM: Interleukin-8 modulates growth and invasiveness of estrogen receptor-negative breast cancer cells. Int J Cancer 121: 1949-1957, 2007.

99. Park SH, Das BB, Casagrande F, Tian Y, Nothnagel HJ, Chu M, Kiefer H, Maier K, De Angelis AA, Marassi FM and Opella SJ: Structure of the chemokine receptor CXCR1 in phospholipid bilayers. Nature 491: 779-783, 2012.

100. Singh JK, Simoes BM, Clarke RB and Bundred NJ: Targeting IL-8 signalling to inhibit breast cancer stem cell activity. Expert Opin Ther Targets 17: 1235-1241, 2013.

101. Singh JK, Simoes BM, Howell SJ, Farnie G and Clarke RB: Recent advances reveal IL-8 signaling as a potential key to targeting breast cancer stem cells. Breast Cancer Res 15: 210 2013.

102. Alfaro C, Teijeira A, Onate C, Pérez G, Sanmamed MF, Andueza MP, Alignani D, Labiano S, Azpilikueta A, Rodriguez-Paulete A et al: Tumor-produced interleukin-8 attracts human myeloid-derived suppressor cells and elicits extrusion of neutrophil extracellular traps (NETs). Clin Cancer Res 22: 3924-3936, 2016.
103. Elliott CL, Allport VC, Loudon JA, Wu GD and Bennett PR Nuclear factor-kappa B is essential for up-regulation of interleukin-8 expression in human amnion and cervical epithelial cells. Mol Hum Reprod 7: 787-790, 2001

104. Wang L, Tang C, Cao H, Li K, Pang X, Zhong L, Dang W, Tang H, Huang Y, Wei L, et al: Activation of IL-8 via PI3K/Akt-dependent pathway is involved in leptin-mediated epithelial-mesenchymal transition in human breast cancer cells. Cancer Biol Ther 16: 1220-1230, 2015.

105. Lian S, Xia Y, Ung TT, Khoi PN, Yoon HJ, Kim NH, Kim KK and Jung YD: Carbon monoxide releasing molecule-2 ameliorates IL-1 $\beta$-induced IL-8 in human gastric cancer cells. Toxicology 361-362: 24-38, 2016.

106. Singh RK, Gutman M, Radinsky R, Bucana CD and Fidler IJ: Expression of interleukin 8 correlates with the metastatic potential of human melanoma cells in nude mice. Cancer Res 54: 3242-3247, 1994.

107. Fernando RI, Hamilton DH, Dominguez C, David JM, McCampbell KK and Palena C: IL-8 signaling is involved in resistance of lung carcinoma cells to erlotinib. Oncotarget 7: 42031-42044, 2016

108. Jiang P, Enomoto A, Jijiwa M, Kato T, Hasegawa T, Ishida M, Sato T, Asai N, Murakumo Y and Takahashi M: An actin-binding protein girdin regulates the motility of breast cancer cells. Cancer Res 68: 1310-1318, 2008.

109. Lin C, Ear J, Pavlova Y, Mittal Y, Kufareva I, Ghassemian M, Abagyan R, Garcia-Marcos M and Ghosh P: Tyrosine phosphorylation of the $\mathrm{G} \alpha$-interacting protein GIV promotes activation of phosphoinositide 3-kinase during cell migration. Sci Signal 4: ra64, 2011.

110. Ni W, Fang Y, Tong L, Tong Z, Yi F, Qiu J, Wang R and Tong X: Girdin regulates the migration and invasion of glioma cells via the PI3K-Akt signaling pathway. Mol Med Rep 12: 5086-5092, 2015.

111. Romashkova JA and Makarov SS: NF-kappaB is a target of AKT in anti-apoptotic PDGF signalling. Nature 401: 86-90, 1999.

112. Jiang BH and Liu LZ: PI3K/PTEN signaling in tumorigenesis and angiogenesis. Biochim Biophys Acta 1784: 150-158, 2008.

113. Abraham RT: Chemokine to the rescue: Interleukin- 8 mediates resistance to PI3K-pathway-targeted therapy in breast cancer. Cancer Cell 22: 703-705, 2012.

114. Hanahan D and Weinberg RA: Hallmarks of cancer: The next generation. Cell 144: 646-674, 2011.

115. Darnell JE: Validating Stat3 in cancer therapy. Nat Med 11: 595-596, 2005.

116. Subramaniam A, Shanmugam MK, Perumal E, Li F, Nachiyappan A, Dai X, Swamy SN, Ahn KS, Kumar AP, Tan BKH, et al: Potential role of signal transducer and activator of transcription (STAT)3 signaling pathway in inflammation, survival, proliferation and invasion of hepatocellular carcinoma. Biochim Biophys Acta 1835: 46-60, 2013.

117. Rajendran P, Li F, Shanmugam MK, Kannaiyan R, Goh JN, Wong KF, Wang W, Khin E, Tergaonkar V, Kumar AP, et al: Celastrol suppresses growth and induces apoptosis of human hepatocellular carcinoma through the modulation of STAT3/JAK2 signaling cascade in vitro and in vivo. Cancer Prev Res (Phila) 5: 631-643, 2012.

118. Samson ME, Porter NG, Hurley DM, Adams SA and Eberth JM: Disparities in breast cancer incidence, mortality, and quality of care among African American and European American women in South Carolina. South Med J 109: 24-30, 2016

This work is licensed under a Creative Commons Attribution-NonCommercial-NoDerivatives 4.0 International (CC BY-NC-ND 4.0) License. 